The essential role of Dnmt1 in gametogenesis in the large milkweed bug

\title{
Oncopeltus fasciatus
}

Joshua T. Washington ${ }^{1}$, Katelyn R. Cavender ${ }^{1}$, Ashley U. Amukamara ${ }^{1}$, Elizabeth C.

McKinney ${ }^{1}$, Robert J. Schmitz ${ }^{2}$, Patricia J. Moore ${ }^{1, *}$

${ }^{1}$ Department of Entomology, University of Georgia

${ }^{2}$ Department of Genetics, University of Georgia

*Patricia J. Moore, 413 Biological Sciences Building, Department of Entomology, University of Georgia, Athens, GA, 30602; (706) 542-0169

Email: pjmoore@uga.edu

Patricia J. Moore: https://orcid.org/0000-0001-9802-7217

Robert J. Schmitz: https://orcid.org/0000-0001-7538-6663

\section{Keywords}

DNA methylation, epigenetics, Dnmt1, spermatogenesis, germ cells, Oncopeltus fasciatu 


\section{Abstract}

2 Given the importance of DNA methylation in protection of the genome against transposable

3 elements and transcriptional regulation in other taxonomic groups, the diversity in both levels

4 and patterns of DNA methylation in the insects raises questions about its function and evolution.

5 We show that the maintenance DNA methyltransferase, DNMT1, affects meiosis and is essential

6 to fertility in milkweed bugs, Oncopeltus fasciatus, while DNA methylation is not required in

7 somatic cells. Our results support the hypothesis that Dnmt1 is required for the transition of germ

8 cells to gametes in $O$. fasciatus and that this function is conserved in male and female

9 gametogenesis. They further suggest that DNMT1 has a function independent of DNA

10 methylation in germ cells. Our results raise the question of how a gene so critical in fitness

11 across multiple insect species can have diverged widely across the insect tree of life. 


\section{Introduction}

14 Despite the apparent ubiquity of DNA methylation across the eukaryotic tree of life (Schmitz et al. 2019, Lewis et al. 2020), in the insects there is considerable variation both in the presence and extent of DNA methylation and even the presence and number of the DNA methyltransferases

17 (Bewick et al. 2016, Lyko 2018, Glastad et al. 2019). Thus, the functional role of DNA methylation and its associated DNA methyltransferases in the insects is unclear. While some

19 studies have associated levels of methylation with gene expression, most studies in the insects

20 find no functional association (Bewick et al. 2016, Glastad et al. 2019).

21 One role emerging from knockdown and silencing studies across several insect species is that

22 Dnmt1 is required for oogenesis (Schulz et al. 2018, Bewick et al. 2019, Gegner et al. 2019,

23 Amukamara et al. 2020). For example, Dnmt1 is required for maintenance of DNA methylation

24 following cell division in the milkweed bug, Oncopeltus fasciatus (Bewick et al. 2019,

25 Amukamara et al. 2020), the downregulation of Dnmt1 using RNAi results in a reduction in

26 methylation and also the cessation of oogenesis. However, it is unclear whether the effect on

27 oogenesis is mediated by the reduction in DNA methylation (Amukamara et al. 2020). While the

28 expected reduction in DNA methylation is seen throughout the organism following Dnmt1

29 knockdown, the only phenotypic consequence is to the germ cells. Evidence from other species

30 supports a function independent of DNA methylation. Dnmt1 is also essential to egg production

31 in T. castaneum (Schulz et al. 2018), a beetle that has no DNA methylation at all (Zemach et al.

32 2010). This suggests that Dnmtl can have a function specific to germ cells in insects that is

33 independent of its function in maintaining DNA methylation. This led us to hypothesize that

34 Dnmt1 plays a role in meiosis in insects (Amukamara et al. 2020). 
35 In this study, we tested the hypothesis that Dnmt1 is essential to gametogenesis in O. fasciatus.

36 Furthermore, if Dnmt1 has a role in gametogenesis, including meiosis, it should be conserved

37 across the sexes. Testing the function of Dnmt1 in males allows us to capitalize on the well-

38 characterized process of spermatogenesis in $O$. fasciatus, specifically (illustrated in Figure 1;

39 Economopoulos \& Gordon 1971), and the conserved features of insect spermatogenesis,

40 generally (Dallai 2014). In O. fasciatus, as in many insects, there are two points in development

41 where meiosis can occur. The first stage where meiosis will occur is during the larval stages.

42 Testis development and spermatogenesis is initiated during larval development in $O$. fasciatus

43 (Economopoulos \& Gordon 1971). During the first three instars the testes consist of seven

44 globular follicles that will develop into the testis tubules (Schmidt et al. 2002). Meiosis is

45 initiated in the $4^{\text {th }}$ instar, and by the end of the $4^{\text {th }}$ instar, cysts containing spermatids are present.

46 Differentiation of the spermatids commences in the $5^{\text {th }}$ instar, and males emerge with up to

47250,000 spermatids that continue to differentiate during sexual maturation. Thus, we can target

48 the developmental time point at which meiosis occurs. In addition, O. fasciatus males can

49 produce gametes throughout their adult lives and therefore meiosis can occur in the adult testis.

50 If Dnmt1 is required for meiosis and gametogenesis we predicted that it will be required both

51 during larval development and as adult males replenish sperm stores following mating. We

52 therefore compared the testis phenotypes of adults developing from nymphs in which Dnmt1

53 expression was downregulated either before or after the major wave of meiosis that occurs in

54 testis development (Economopoulos \& Gordon 1971, Schmidt et al. 2002, Ewen-Campen et al

55 2013). We also treated sexually mature adults, and examined fertility in males following sperm

56 depletion, testing for the ability of knockdown males to replenish sperm stores following

57 multiple matings. Our results demonstrated that expression of Dnmt1 is required for the 
58 development of sperm both during larval and adult spermatogenesis and that the impact of

59 Dnmt1 knockdown was greatest if it occurred prior to the onset of meiotic divisions in the

60 developing testes. These results establish that Dnmt1 plays a critical conserved function across

61 the sexes during gametogenesis in $O$. fasciatus and that it is required for germ cell development.

Results

The pattern of Dnmt1 expression during testis development and across tissues suggests a role in spermatogenesis.

65 We measured Dnmt1 expression during larval development and sexual maturation. Our

66 prediction was that if Dnmt1 is required during gametogenesis, particularly meiosis, then its

67 expression should mirror those of two genes known to be involved in germ cell development,

68 Boule and Vasa (Shah et al. 2010, Yajima \& Wessel 2011). Thus, we predicted that Dnmt1

69 expression would be highest during the stages when gametogenesis is occurring. As predicted,

70 testis-specific expression of Dnmt1 is highest during the $4^{\text {th }}$ and $5^{\text {th }}$ instars of development

71 (Figure 2A; ANOVA, $\mathrm{F}=27.426$, d.f. $=3,38, \mathrm{p}<0.001$ ), stages when meiosis and

72 spermatogenesis is most active (Economopoulos \& Gordon 1971). The expression is lowest in

73 virgin adult males. This expression pattern mirrored that observed for Boule, a gene with a well-

74 characterized role in meiosis (Figure 2B; ANOVA, $\mathrm{F}=36.346$, d.f. $=3,38, \mathrm{p}<0.001$ ). Dnmt1

75 expression pattern was also similar to Vasa, a highly conserved marker of the germline (Figure

76 2C; ANOVA, $\mathrm{F}=20.444$, d.f. $=3,38, \mathrm{p}<0.001$ ). While Dnmt1 is expressed across all adult

77 tissues, as would be expected given its role in maintenance of DNA methylation, expression is

78 highest in testes compared to gut, head, and muscle tissue (Figure 2-figure supplement 1;

79 ANOVA, $\mathrm{F}=67.311$, d.f. $=3,36, \mathrm{p}<0.001$ ), also suggesting a special role during

80 gametogenesis. 


\section{Dnmt1 knockdown reduced levels of DNA methylation in the testis genome.}

82 To confirm the effectiveness of our RNAi treatment, we measured expression of Dnmt1 in a

83 subset of ds-RED and ds-Dnmt1 injected males (Figure 3). Quantitative PCR demonstrated

84 reduced levels of Dnmt1 mRNA in ds-Dnmt1 injected males compared to ds-RED injected males

85 in both $3^{\text {rd }}$ instar $($ ANOVA; $F=83.126$, d.f. $=1,31, p<0.001)$ and $5^{\text {th }}$ instar $(A N O V A ; F=$

8649.793 , d.f. $=1,22, \mathrm{p}<0.001)$ treated males 6 to 10 days following injection with dsRNA.

87 Treatment of males with ds-Dnmt1 had the predicted effect on Dnmt1 function in maintenance of

88 methylation. We performed whole genome bisulfite sequencing to evaluate the impact of the ds-

89 Dnmt1 on DNA methylation genome wide. The reduction in expression of Dnmt1 in the RNAi

90 individuals had the expected phenotypic effect on DNA methylation with a reduction of genome

91 methylation in the testes for ds-Dnmt1 treated males, but not control males (Figure 3-figure

92 supplement 1). Genomic DNA from the testes of control treated males had approximately $12.5 \%$

$93 \mathrm{CpG}$ methylation regardless of stage they were treated. Knockdown of Dnmt1 at the earlier stage

94 of development led to a greater percentage reduction of methylation. Treatment with ds-Dnmt1 at

95 the $5^{\text {th }}$ instar reduced the percent $\mathrm{CpG}$ methylation from around $12.5 \%$ to around $5 \%$. Treatment

96 with ds-Dnmt1 at the $3^{\text {rd }}$ instar reduced the level of methylation even further, to around $2 \%$, as

97 predicted given the greater numbers of cell divisions that were expected between treatment and

98 sampling between these two treatments.

\section{Dnmt1 knockdown affected testis size and structure.}

100 Knockdown of Dnmt1 prior to meiosis, in the $3^{\text {rd }}$ instar stage, had a significant effect on testis

101 size in virgin males, while knockdown of Dnmt1 during the developmental stage after which

102 meiosis is initiated, the $5^{\text {th }}$ instar stage, had no effect on testis size (Figure 4; ANOVA, F =

10320.360 , d.f. $=4,58, \mathrm{p}<0.001)$ compared to either uninjected controls or ds-RED treated males. 
104 Knockdown of Dnmt1 prior to meiosis affected testis tubules to a greater extent than knockdown

105 following the initiation of meiosis during larval testis development (Figure 5). Control males

106 injected in the $3^{\text {rd }}$ or $5^{\text {th }}$ instar stage of development showed the expected structure of the testis

107 tubule (Figure 5A and $\mathrm{C}$ ). At the anterior end of the testis tubule, spermatogonia and primary

108 spermatocytes had the characteristic nuclear structure and there was clear evidence of mitotic

109 division within the spermatogonia (Figure 5C, arrowhead), using $\alpha$-phosphohistone H3 (pHH3)

110 to stain for chromosome condensation in preparation for mitosis and meiosis. We also observed

$111 \alpha-$ pHH3 staining in spermatocysts at the border between primary and secondary spermatocytes

112 in the control testis tubules in both $3^{\text {rd }}$ and $5^{\text {th }}$ instar treated males. Following this band of

113 relatively synchronous meiotic activity, the posterior testis tubule showed spermatids and

114 developing spermatozoa as they matured. We confirmed the use of this band of $\alpha-\mathrm{pHH} 3$ stained 115 spermatocysts as a landmark of meiosis using knockdown of Boule (Figure 5-figure supplement $1161)$.

117 The structure of the testis tubules of males treated with ds-Dnmt 1 in the $3^{\text {rd }}$ instar was highly 118 disrupted and both the anterior and posterior testis tubule was affected (Figure 5B). There were

119 fewer spermatocysts in both the region of spermatogonia and primary spermatocytes. While

120 there were occasional $\alpha$-pHH3 positive nuclei, these were not well organized into spermatocysts

121 and were spread throughout the testis tubule rather than organized at the junction between

122 primary and secondary spermatocytes. There was evidence of mitotic activity in the

123 spermatogonia (Figure 5B arrowhead), although these were less frequent in ds-Dnmt1 treated

124 males than control males. The testis tubules of males treated with ds-Dnmt1 in the $5^{\text {th }}$ instar stage 125 of development had a structure much more similar to control males (Figure 5D). Mitotic activity 126 was apparent in the spermatogonia (Figure 5D arrowhead) and most testis tubules had evidence 
127 of mature sperm and $\alpha-\mathrm{pHH} 3$ stained spermatocysts at the junction between primary and

128 secondary spermatocytes (Figure 5D arrow). Unorganized spermatocysts below this junction

129 were frequently observed, however, and ds-Dnmt 1 males treated at the $5^{\text {th }}$ instar had variable

130 phenotypes posterior to the primary spermatocytes, presumably depending on when treatment

131 occurred following the wave of meiosis along the testis tubule axis.

\section{Dnmt1 knockdown in adult males prevented replenishment of sperm stores}

133 Downregulating Dnmt1 expression in adult males resulted in a loss of fecundity over time. The

134 third and final females mated to ds-Dnmt1 treated males ran out of sperm to fertilize eggs more

135 rapidly than those mated to control males. Clutches of eggs laid by females mated to ds-Dnmt1

136 treated males were not fertilized and failed to hatch at an earlier collection day than those laid by

137 females mated to control males (Figure 6; Wilcoxon $\chi^{2}=13.978$, d. f. $=1, \mathrm{p}<0.001$ ).

138 The loss of fertility in males was associated with smaller testis size. Males treated with ds-Dnmt1

139 at seven days post-emergence and then allowed to mate for three weeks prior to dissection had

140 statistically significantly smaller testis area than the testes of control males after the same mating

141 treatment (ANOVA, $\mathrm{F}=29.084$, d.f. $=1,51, \mathrm{p}<0.001$; Figure 6-figure supplement 1 ). The

142 smaller testis area of ds-Dnmt1 treated adult males was associated with a breakdown in testis

143 tubule structure and the loss of sperm from the testis tubules (Figure 7). In control males, three

144 weeks post injection the regions of spermatogenesis were recognizable. Small spermatocysts

145 with spermatogonia undergoing mitotic divisions were observable at the anterior tip of the testis

146 tubule (Figure 7A and B). Posterior to the spermatogonia were the primary spermatocytes with

147 more diffuse nuclear structure. We often observed the band of $\alpha$-pHH3 positive spermatocysts

148 that indicated the first meiotic division to form the secondary spermatocytes. At the most

149 posterior end of the testis tubule the spermatids developed into spermatozoa. Three weeks after 
150 Dnmt1 knockdown testis tubule structure is significantly disrupted. There appeared to be fewer

151 spermatogonia and those that remained had a more condensed nuclear structure than in the testis

152 tubules of control males (Figure 7C and D). The most noticable effect was seen in the region

153 containing the spermatocytes. There were few primary spermatocytes in the testis tubule and $\alpha$ -

$154 \mathrm{pHH} 3$ positively stained spermatocysts were rarely observed, indicating few spermatocysts

155 undergoing meiosis.

Discussion

157 The function of DNA methylation and the DNA methylation enzymes across the insect tree of

158 life has been widely debated, particularly in light of the extreme variation in presence of this

159 chromatin modification and the diversification of the enzymatic toolkit required to methylate

160 DNA de novo and maintain DNA methylation patterns (Bewick et al. 2016, Lyko 2018, Lewis et

161 al. 2020). This evolutionary pattern is particularly intriguing given that in two species on

162 divergent branches of the insect phylogeny the maintenance methyltransferase DNMT1 is

163 essential to gametogenesis, and thus is tightly tied to fitness, even in a species where DNA

164 methylation itself is absent (Schulz et al. 2018). While functional studies have not been done in

165 other species, a summary of expression studies on the DNA methyltransferases across a diversity

166 of insects suggest that these enzymes could be involved in gametogenesis across a number of

167 species, ranging from fire ants, Solenopsis invicta (Kay et al. 2018), to jewel wasps, Nasonia

168 vitripennis (Zwier et al. 2012), to migratory locusts, Locusta migratoria (Robinson et al. 2016),

169 and the brown plant hopper, Nilaparvata lugens (Zhang et al. 2015). Here we showed that Dnmt1

170 expression affects germ cell development. The effect of downregulating Dnmt1 in males, as in

171 females (Amukamara et al. 2020), was specific to the germ cells. The downregulation of Dnmt1

172 did result in reduction of DNA methylation, but there were no obvious morphological impacts to 
173 the RNAi-treated individuals. Our results show that the function of Dnmt1 in germ cells is

174 conserved across the sexes within a species, and other results document that Dnmt1 expression is

175 required for oogenesis among species. This raises a conundrum when we look across the insect

176 tree of life. How can a gene required for such a fundamental fitness activity in examples from

177 such a diverse group of insects also be so evolutionarily labile? This suggests that the function

178 Dnmt1 in germ cell development is easily lost or replaced.

Dnmt1 knockdown causes inhibition of spermatogenesis consistent with a role in meiosis

180 If our hypothesis on the role of Dnmt1 in meiosis is correct, then spermatogenesis should be

181 affected by Dntrl expression as well as oogenesis, as it is a shared process across

182 gametogenesis during sexual reproduction. In the testes $O$. fasciatus males, we observed both

183 spermatogonia and primary spermatocytes that stain positively for phosphorylation of the serine

18410 residue of histone protein $\mathrm{H} 3$. While the pattern of histone $\mathrm{H} 3$ phosphorylation across meiosis

185 has not been specifically studied in $O$. fasciatus, phosphorylation of the serine 10 is typically

186 associated with chromosome condensation during meiosis (Hans and Dimitrov 2001) and mitosis

187 (Prigent and Dimitrov 2003). Moreover, the pattern of $\alpha-\mathrm{pHH} 3$ staining along the axis of the

188 testis tubule is consistent with this histone modification occurring in both mitosis and meiosis.

189 We observed $\alpha-\mathrm{pHH} 3$ positive cells both within spermatocysts containing the mitotically

190 dividing spermatogonia and also at the boundary between primary and secondary spermatocytes.

191 We have confirmed this landmark using Boule knockdown males. In Drosophila, Boule is

192 required for progression of spermatocytes through meiosis. Germ cells lacking functional Boule

193 become arrested at meiotic prophase (Eberhart et al. 1996). In the testes of $O$. fasciatus males

194 treated with ds-Boule, the affected cells were all posterior to the band of synchronous $\alpha-\mathrm{pHH} 3$

195 positive spermatocytes. Thus, $\alpha-\mathrm{pHH} 3$ staining provided a landmark for entry into meiosis. 
196 We did not see the band of $\alpha$-pHH3 positive spermatocysts at the border between primary and

197 secondary spermatocytes in the Dnmt1 knockdown males treated at the $3^{\text {rd }}$ instar stage of

198 development. This could be interpreted as the primary spermatocytes have not initiated

199 chromosome condensation. However, we did observe individual $\alpha-\mathrm{pHH} 3$ positive nuclei in the

200 posterior testis tubule. So there could have been arrest after chromatin condensation with a

201 breakdown in spermatocyst structure. Interestingly, the testis phenotype of our Dnmt1

202 knockdown males resembled the phenotypic effect of Vasa knockdown reported by Ewen

203 Campen et al. 2013. Vasa RNAi results in defects in cyst integrity and Ewen Campen et al.

204 (2013) propose that Vasa plays a specific role in the onset or synchrony of meiosis. Vasa has also

205 been proposed to be required for the correct progression through meiosis in mice (Tanaka et al.

206 2000) and humans (Medrano et al. 2012). Thus, the phenotypic similarity between Dnmt1

207 knockdown and Vasa knockdown testes in O. faciatus support the hypothesis that Dnmt1 may be

208 required for the successful initiation and completion of meiosis in spermatocytes. More work

209 remains to determine exactly what stage of sperm development is impacted by the decrease in

210 Dnmt1 expression.

211 The phenotype of knockdown of Dnmt1 is exacerbated when knockdown occurs prior to the

212 stage of testis development when meiosis occurs. This result is consistent with what was

213 observed in female O. fasciatus (Amukamara et al. 2020) in which knockdown of Dnmt1

214 expression prior to the stage of oocyte development inhibited all oocyte formation. One

215 interpretation of this result is that Dnmt 1 is required for successful progression through meiosis.

216 However, it is clear that reducing Dnmt1 expression had an impact beyond simply reducing the

217 ability to enter or complete meiosis. A block to progression through meiosis, as demonstrated by

218 the Boule knockdown, spermatogonia and primary spermatocytes would continue to be born but 
219 remain viable after a failure to complete meiosis. In the Dnmt1 knockdowns, however, there

220 were fewer germ cells of any type, and those that remained in the testis tubule often appeared to

221 have abnormal and condensed nuclei. It remains to be determined if Dnmt1 is required for

222 meiosis or if the association with meiosis is a correlation; Dnmt1 could be required for viability

223 of germ cells and act at the stage of development at which they would be undergoing meiosis.

224 Previous studies on the function of Dnmt1 in insect spermatogenesis have not documented any

225 effect on male fertility. Knockdown of Dnmt1 in the red flour beetle, T. castaneum (Schulz et al.

226 2018) had no effect on the fecundity of female mating partners was measured in the first nine

227 days post mating and the authors conclude that Dnmt1 is not required for spermatogenesis in $T$.

228 castaneum. We suspect that the function of Dnmt1 in spermatogenesis is not unique to $O$.

229 fasciatus, given the expression patterns of Dnmt1 in other insects (Robinson et al. 2016, Kay et

230 al. 2018). In the T. castaneum study, the authors did not examine testis structure or design a

231 mating strategy that would exhaust the sperm stores of the males and so may have missed a

232 fertility effect. In holometabolous insects, including beetles, spermatocytes are typically formed

233 by the end of larval development (Economopoulos \& Gordon 1971), thus males treated as pupae

234 would still emerge with large numbers of sperm in their testes. Here we showed that male $O$.

235 fasciatus treated with ds-Dnmt1 RNA as sexually mature adults become sperm limited more

236 rapidly than control males. There is a potential alternative explanation, that Dnmt1 knockdown

237 males could continue to produce sperm but that sperm was of low quality and unable to support

238 development. Given that the testes of ds-Dnmt1 treated males were significantly smaller than

239 control males and had altered testis tubule structure, which indicated that spermatogenesis was

240 significantly impacted, we concluded that Dnmt1 knockdown males are unable to replenish

241 sperm supplies. The functional role of Dnmt1 in testes across other species remains to be tested. 


\section{DNA methylation and germ cell development}

243 The knockdown of Dnmt1 resulted in a reduction of DNA methylation within the testes, as

244 predicted. The effect was greater in the nymphs that were treated in an earlier stage of

245 development, as would be expected given the greater number of cell divisions that would occur

246 between treatment and collection of the testes between the $3^{\text {rd }}$ and $5^{\text {th }}$ instar treatments. The more

247 extreme phenotype in the $3^{\text {rd }}$ instar treated males could be explained by the greater reduction in

248 methylated CpG. However, the percent methylation seen in the testes of the $5^{\text {th }}$ instar ds-Dnmt1

249 treated males was similar to that seen in females treated at the $4^{\text {th }}$ instar stage of development

250 (Amukamara et al. 2020), greater than a two-fold reduction in the percent methylated CpG

251 residues. In Dnmt1 knockdown females, there was a compete loss of oocyte production when

252 DNA methylation was reduced to this level while in males the phenotype of the $5^{\text {th }}$ instar Dnmt 1

253 knockdowns was close to normal. This disconnect between reduction of DNA methylation and

254 phenotypic effects mirrors what has been seen in the beetle, T. castaneum (Schulz et al. 2018). In

255 this species, the reduction of DNA methylation is an evolved difference rather than an

256 experimental effect, but the results are similar to what we have observed in O. fasciatus; DNA

257 methylation is not required for function of somatic cells, but downregulation of Dnmt1

258 expression leads to specific germ cell effects. The lack of correlation between extent of

259 methylation and function in germ cells strengthens our hypothesis that there may be a pleiotropic

260 function for Dnmt1 in germ cells that acts independently of DNA methylation levels.

261 Alternatively, DNA methylation may have a specific role in the germ cells that it does not play in

262 somatic cells. Perhaps DNA methylation is required for proper gene expression in germ cells or

263 it may be required for transposon silencing only in germ cells. However, demethylation of

264 ovarian tissue in $O$. fasciatus showed little relationship between methylation levels and gene 
265 expression, with few differentially transcribed genes (Bewick et al. 2019). Another possibility is

266 that DNA methylation state may be a prerequisite for successful completion of meiosis and not

267 mitosis. For example, O. fasciatus has holocentric chromosomes and undergoes inverted meiosis

268 (Viera et al. 2009). During mitosis chromosomes have a kinetocore that extends across the

269 majority of the chromosome but in meiosis, the kinetochore plate is missing and microtubules

270 extend into the chromosome (Comings \& Okada 1972). One could imagine that DNA

271 methylation might be required for this interaction. However, the complete lack of methylation

272 but a functional role of Dnmt1 in T. casteneum oogenesis alongside our results argues for a

273 pleiotropic function for Dnmt1 in gametogenesis that is independent of its role in DNA

274 methylation.

\section{Conclusion}

276 Dnmt1 expression is required for germ cell development in both male and female $O$. fasciatus.

277 The block to germ cell development in Dnmt1 knockdowns appeared to be associated with

278 meiosis, although it was not a simple block to progression through meiosis as germ cells are lost

279 from the testes. Thus, Dnmt1 may be required for germ cell viability. It still remains to be

280 determined if the block in gametogenesis depends on DNA methylation or an alternative

281 function of Dnmt1, as suggested by the requirement for Dnmt1 during gametogenesis in an insect

282 with a non-methylated genome (Schultz et al. 2018). Whatever the specific function of Dnmt1 in

283 gametogenesis, the requirement for this enzyme in such a critical fitness function as the

284 production of gametes in representatives of different groups of insects raises important questions

285 as to how this enzyme and the entire methylation toolkit has evolved across the insect tree of life

286 (Lyko et al 2018, Provataris et al. 2018). Functional analysis of Dnmt1 in the insect groups

287 where it is found, and study of how these functions are replaced in the species where it is no 
288 longer found, will be essential for understanding the evolution of this important base

289 modification.

Materials and Methods

\begin{tabular}{|c|c|c|c|c|}
\hline \multicolumn{5}{|c|}{ Key Resources Table } \\
\hline $\begin{array}{l}\text { Reagent type } \\
\text { (species) or } \\
\text { resource }\end{array}$ & Designation & $\begin{array}{l}\text { Source or } \\
\text { reference }\end{array}$ & Identifiers & $\begin{array}{l}\text { Additional } \\
\text { information }\end{array}$ \\
\hline $\begin{array}{l}\text { strain, strain } \\
\text { background }\end{array}$ & $\begin{array}{l}\text { Oncopeltus } \\
\text { fasciatus }\end{array}$ & $\begin{array}{l}\text { Carolina } \\
\text { Biologicals }\end{array}$ & $\begin{array}{l}\text { Item \# } 143810 \\
\text { NCBI } \\
\text { Taxon:7535 }\end{array}$ & $\begin{array}{l}\text { Cultured in } \\
\text { Moore lab for } \\
5 \text { years }\end{array}$ \\
\hline antibody & $\begin{array}{l}\text { anti- } \\
\text { phospho- } \\
\text { Histone H3 } \\
\text { (Ser10) } \\
\text { (Rabbit } \\
\text { polyclonal) }\end{array}$ & Millipore & $\begin{array}{l}\text { Cat \# 06-570 } \\
\text { RRID:AB_31017 } \\
7\end{array}$ & IF $(1: 1000)$ \\
\hline $\begin{array}{l}\text { commercial } \\
\text { assay or kit }\end{array}$ & $\begin{array}{l}\text { Qiagen RNA } \\
\text { easy kit with } \\
\text { Qiazol }\end{array}$ & Qiagen & Cat \# 74104 & \\
\hline $\begin{array}{l}\text { commercial } \\
\text { assay or kit }\end{array}$ & $\begin{array}{l}\text { LightCycler } \\
480 \text { SYBR } \\
\text { Green I } \\
\text { Master }\end{array}$ & Roche & $\begin{array}{l}\text { Product No. } \\
04707516001\end{array}$ & \\
\hline $\begin{array}{l}\text { commercial } \\
\text { assay or kit }\end{array}$ & $\begin{array}{l}\text { MEGAscript } \\
\text { T7 } \\
\text { Transcriptio } \\
\text { n kit }\end{array}$ & $\begin{array}{l}\text { ThermoFisher } \\
\text { Scientific }\end{array}$ & AMB13345 & \\
\hline $\begin{array}{l}\text { sequence-based } \\
\text { reagent }\end{array}$ & $\begin{array}{l}\text { ds-Dnmt1 } \\
\text { RNAi primer } \\
\text { set for } \\
\text { transcription } \\
\text { template }\end{array}$ & $\begin{array}{l}\text { Amukamara et } \\
\text { al. } 2020\end{array}$ & PCR primers & $\begin{array}{l}\text { Sense: } \\
\text { TGATGCTCG } \\
\text { GCCTCAAAAC } \\
\text { AAGAT } \\
\text { Anti-sense: } \\
\text { ACTCCAGGA } \\
\text { GGTGGAACA } \\
\text { GTAGTCT }\end{array}$ \\
\hline
\end{tabular}




\begin{tabular}{|c|c|c|c|c|}
\hline $\begin{array}{l}\text { sequenced-based } \\
\text { reagent }\end{array}$ & $\begin{array}{l}\text { ds-Boule } \\
\text { RNAi primer } \\
\text { set for } \\
\text { transcription } \\
\text { template }\end{array}$ & $\begin{array}{l}\text { Amukamara et } \\
\text { al. } 2020\end{array}$ & PCR primers & $\begin{array}{l}\text { Sense: } \\
\text { AGCCTCACCA } \\
\text { CCAGTATTCG } \\
\text { Anti-sense } \\
\text { AGGGTGCCT } \\
\text { AGGATTGGA } \\
\text { CT }\end{array}$ \\
\hline $\begin{array}{l}\text { sequenced-based } \\
\text { reagent }\end{array}$ & $\begin{array}{l}\text { qRT-PCR } \\
\text { primer set: } \\
\text { Dnmt1 }\end{array}$ & $\begin{array}{l}\text { Amukamara et } \\
\text { al. } 2020\end{array}$ & PCR primers & $\begin{array}{l}\text { Sense: } \\
\text { GCTTGGACA } \\
\text { AAGGCTACT } \\
\text { ACT } \\
\text { Anti-sense: } \\
\text { CTTCGTGGTC } \\
\text { CCTTATCCTT } \\
\text { ATC }\end{array}$ \\
\hline $\begin{array}{l}\text { sequenced-based } \\
\text { reagent }\end{array}$ & $\begin{array}{l}\text { qRT-PCR } \\
\text { primer set: } \\
\text { Boule }\end{array}$ & $\begin{array}{l}\text { Amukamara et } \\
\text { al. } 2020\end{array}$ & PCR primers & $\begin{array}{l}\text { Sense: } \\
\text { TATTCGTACC } \\
\text { ACCCTCTTCC } \\
\text { Anti-sense: } \\
\text { GACAATGGC } \\
\text { TGGGTCATA } \\
\text { AG }\end{array}$ \\
\hline $\begin{array}{l}\text { sequenced-based } \\
\text { reagent }\end{array}$ & $\begin{array}{l}\text { qRT-PCR } \\
\text { primer set: } \\
\text { Vasa }\end{array}$ & $\begin{array}{l}\text { Amukamara et } \\
\text { al. } 2020\end{array}$ & PCR primers & $\begin{array}{l}\text { Sense: } \\
\text { CTGTTGCTCC } \\
\text { TCAGGTTAT } \\
\text { T } \\
\text { Anti-sense: } \\
\text { CATTAAGCCT } \\
\text { TCCAGGAGT } \\
\text { AG }\end{array}$ \\
\hline $\begin{array}{l}\text { sequenced-based } \\
\text { reagent }\end{array}$ & $\begin{array}{l}\text { qRT-PCR } \\
\text { primer set: } \\
\text { actin }\end{array}$ & $\begin{array}{l}\text { Amukamara et } \\
\text { al. } 2020\end{array}$ & PCR primers & $\begin{array}{l}\text { Sense: } \\
\text { CTGTCTCCCG } \\
\text { AAAGAGAAT } \\
\text { ATG } \\
\text { Anti-sense: } \\
\text { TCTGTATGG } \\
\text { ATTGGAGGA } \\
\text { TCTA }\end{array}$ \\
\hline $\begin{array}{l}\text { sequenced-based } \\
\text { reagent }\end{array}$ & $\begin{array}{l}\text { qRT-PCR } \\
\text { primer set: } \\
\text { GAPDH }\end{array}$ & $\begin{array}{l}\text { Amukamara et } \\
\text { al. } 2020\end{array}$ & PCR primers & $\begin{array}{l}\text { Sense: } \\
\text { ACGGTTTCA } \\
\text { AGGAGAAGT } \\
\text { TAG } \\
\text { Anti-sense: } \\
\text { AGCTGATGG }\end{array}$ \\
\hline
\end{tabular}




\begin{tabular}{|l|l|l|l|l|}
\hline & & & & $\begin{array}{l}\text { TGCAGTTAT } \\
\text { G }\end{array}$ \\
\hline $\begin{array}{l}\text { software, } \\
\text { algorithm }\end{array}$ & JMP Pro & SAS Institute & $\begin{array}{l}\text { Version 14.1 } \\
\text { RRID:SCR_014 } \\
242\end{array}$ & \\
\hline other & DAPI stain & Invitrogen & D1306 & $0.5 \mu \mathrm{g} / \mathrm{mL}$ \\
\hline
\end{tabular}

\section{Animal care}

292 All experimental animals were from colonies of laboratory reared O. fasciatus (Carolina

293 Biologicals, Burlington, NC) and were reared under standard rearing conditions of $12 \mathrm{hr}: 12 \mathrm{hr}$

294 light/dark at $27^{\circ} \mathrm{C}$. To collect animals of known age and social conditions, eggs were removed

295 from the mass colonies and allowed to hatch in plastic storage containers containing ad libitum

296 deionized water and organic, raw sunflower seeds. For the nymph injections, nymphs were

297 pulled from mixed sex nymph colonies at the $3^{\text {rd }}$ instar or $5^{\text {th }}$ instar. For adult injections, nymphs

298 were separated by sex at the $4^{\text {th }}$ instar and housed in single sex colonies. These were checked

299 daily and newly emerged adults. All experimental animals were placed into individual petri

300 dishes with food and water.

\section{Developmental expression}

302 Given our hypothesis that Dnmt1 is required for development of germ cells and meiosis we

303 examined the expression levels of Dnmt1 across testis development in males. Groups of nymphs

304 were staged and sexed. Testes were dissected from $4^{\text {th }}$ and $5^{\text {th }}$ instar nymphs and flash frozen in

305 liquid nitrogen and stored at $-80^{\circ} \mathrm{C}$. We also collected testes from virgin males on the day of

306 adult emergence and after sexual maturation at 7 days post-adult-emergence. We also collected 
307 head, gut, and muscle samples from the sexually mature adult male individuals for tissue specific

308 expression.

309 Total RNA was extracted using a Qiagen RNA easy kit with Qiazol (Qiagen, Venlo, The

310 Netherlands) and complementary DNA (cDNA) synthesized from 500 ng RNA with aScript

311 cDNA Super-Mix (Quanta Biosciences, Gaithersburg, MD). Quantitative real-time PCR (qRT-

312 PCR) was used to determine expression levels of Dnmtl and two genes with known functions in

313 spermatogenesis, Boule and Vasa. Primers are described in Amukamara et al. 2020. As in

314 Amukamara et al. 2020, actin and GAPDH were used as reference genes. We have previously

315 validated these reference genes and they are accepted as robust reference genes in $O$. fasciatus

316 (Meinzer et al. 2019). We used a Roche LightCycler 480 with the SYBR Green Master Mix

317 (Roche Applied Science Indianapolis, IN). All samples were run with 3 technical replicates using

$31810 \mu \mathrm{L}$ reactions. There were 10 biological replicates for each stage. Each biological replicate of

$3192^{\text {nd }}, 3^{\text {rd, }} 4^{\text {th }}$, and $5^{\text {th }}$ instar nymphs consisted of pools of $10,5,4$, and 3 individuals, respectively.

320 Adult replicates consisted of individual animals. Sample size was based on past experience

321 balanced by the cost of qRT-PCR. Primer efficiency calculations, genomic contamination

322 testing, and endogenous control gene selection were performed as described in Cunningham et

323 al. 2014. We used the $\Delta \Delta \mathrm{CT}$ method to compare levels of gene expression across the samples

324 (Livak and Schmittgen 2001). Gene expression was standardized per individual to account for

325 different numbers of individuals within each group at each developmental stage. Differences in

326 expression levels were analyzed using ANOVA in JMP Pro v14. If there was a significant

327 overall effect, we compared means using Tukey-Kramer HSD.

\section{RNAi preparation}


329 Double-stranded RNAs were prepared as described in Amukamara et al. 2020. Briefly, DNA

330 templates were prepared by PCR using gene-specific primers (Amukamara et al. 2020). Sense

331 and anti-sense RNA were transcribed together with an Ambion MEGAscript kit (ThermoFisher

332 Sci, Waltham, MA) and allowed to anneal to form a 404 bp ds-Dnmt1 RNA. The concentration

333 of dsRNA was adjusted to $3 \mu \mathrm{g} / \mu \mathrm{L}$ in injection buffer $\left(5 \mathrm{mM} \mathrm{KCl}, 0.1 \mathrm{mM} \mathrm{NaH}_{2} \mathrm{PO}_{4}\right)$.

\section{Nymph injections, testis size and morphology}

335 To examine the effect of Dnmtl knockdown prior to or following the wave of meiosis initiated in

336 the $4^{\text {th }}$ instar stage, nymphs were injected with ds-Dnmt1 or control ds-RED injections at either

337 the $3^{\text {rd }}$ instar or $5^{\text {th }}$ instar stage of development. For further information on controls and testing

338 for potential off-target effects please see Amukamara et al. 2020. Nymphs were anaesthetized at

$3394^{\circ} \mathrm{C}$ for 20 minutes prior to injection. Nymphs were injected in the abdomen using pulled glass

340 capillary needles (Sutter Instrument Company micropipette puller model P-97, Novato, CA)

341 between the third and fourth abdominal segments (Chesebro et al. 2009). Nymphs were injected

342 with $2 \mu \mathrm{L}$ volume for all injections. Following injections, nymphs were placed in individual petri

343 dishes and monitored for development. Date of adult emergence was recorded. We did not do a

344 power analysis, but based on preliminary data on the strength of the effect we aimed for 25

345 individual males for each treatment. Males were randomly assigned to a treatment group. Not all

346 males survived to age of dissection, resulting in final sample sizes of 22 and 19 for $3^{\text {rd }}$ instar

347 males injected with buffer and ds-Dnmt1, respectively and 25 and 20 for $5^{\text {th }}$ instar males injected

348 with buffer and ds-Dnmt1, respectively.

349 Testis size: At 7 to 10 days post-adult emergence, virgin males were dissected and their testes

350 were removed. Whole testes were allowed to settle into $1 \mathrm{~mL}$ Phosphate Buffered Saline (PBS)

351 and were imaged with a Leica M60 Stereomicroscope with Leica Application Suite software 
352 (LAS v4). Testis area was measured on one of the pair from each male with the LAS by

353 outlining the whole testis with all 7 testis tubules. Differences in testis area were analyzed using

354 ANOVA in JMP Pro v14.

355 Testis tubule structure: O. fasciatus testes contain 7 individual testis tubules surrounded by a

356 relatively impermeable, autofluorescent membrane. Individual testis tubules were removed from

357 the outer membranous sheath for fixation and staining. Males from each treatment were dissected

358 across 4 dissection days. Testis tubules from individual males within a treatment were pooled for

359 staining. Thus each day one tube was a replicate with tubules from several individual males.

360 Tubules were fixed for 30 minutes in 4\% formaldehyde in PBS plus $0.1 \%$ Triton-X100 (PBT)

361 and stained for evidence of cell division using an $\alpha$-phosphohistone H3 Ser10 (pHH3) primary

362 antibody (Millipore antibody 06-570, Sigma-Aldrich, St. Louis, MO). $\alpha$-phosphohistone H3

363 (pHH3) stains for chromosome condensation in preparation for mitosis and meiosis (Hans \&

364 Dimitrov 2001, Prigent \& Dimitrov 2003). The secondary antibody was an Alexa Fluor goat-

365 anti-rabbit 647 (ThermoFisher Scientific, Waltham, MA). Following antibody staining the

366 tubules were stained with DAPI $(0.5 \mu \mathrm{g} / \mathrm{mL}$ PBT $)$ to visualize nucleic acids. Stained tubules

367 were mounted in Mowiol 4-88 mounting medium (Sigma-Aldrich, St. Louis, MO) and visualized

368 with an Olympus BX51 Fluorescent microscope. Images were taken of every testis tubules

369 present on each slide. Representative images are presented in the figures.

\section{Quantitative Real Time PCR}

371 While we had evidence that all our RNAi treatments successfully knocked down expression in

372 females (Amukamara et al. 2020), to confirm that our RNAi treatment was effective in males,

373 total RNA and genomic DNA was extracted from flash frozen testes of a subsample of males 6

374 to 10 days following injection with the dsRNA using a Qiagen Allprep DNA/RNA Mini Kit 
375 (Qiagen, Venlo, The Netherlands). Expression levels for Dnmt1 was analyzed using qRT-PCR as

376 described above.

\section{Quantification of DNA methylation}

378 The DNA from each prep used for qRT-PCR was used to prepare MethylC-seq libraries as

379 described in Urich et al. 2015 and Amukamara et al. 2020. Samples were sequenced on a

380 NextSeq500 and qualified reads were aligned to the $O$. fasciatus genome assembly according to

381 previously published methods (Schmitz et al. 2013). The percent DNA methylation was

382 calculated by dividing the total number of methylated $\mathrm{CpG}$ sites by the total number of $\mathrm{CpG}$ sites

383 (Schultz et al. 2012). Spiked in Lambda DNA, which is fully demethylated, was used as a control

384 for the sodium bisulfite conversion rate of unmodified cytosines. Three individuals were

385 sequenced for each treatment.

\section{Adult injections}

387 RNAi treatment: Sexually mature virgin males (7 days post-adult-emergence) were injected with

$3883 \mu \mathrm{L}$ ds-Dnmt1 RNA or control injections using a pulled glass capillary needle between the third

389 and fourth abdominal segments (Chesebro et al. 2009). Control injections for the male fecundity

390 experiments were injection buffer alone. We used ds-RED control injections for the testis

391 imaging experiment. Previous studies from our lab have shown no difference in buffer alone

392 controls or non-specific ds-RNA (Bewick et al. 2019). Following injection males were placed

393 into individual petri dishes and provided with ad libitum food and water. We did not do a power

394 analysis, but based on preliminary data on the strength of the effect we aimed for 30 individual

395 males for each treatment. Males were randomly assigned to a treatment group. 
Male fecundity: Preliminary experiments had shown that two previous matings were required to deplete sperm stores. Therefore, in order to allow males to deplete sperm stores acquired during nymphal development and sexual maturation, males were placed in mating trials with three 7- to 10-day-old virgin females, one provided each week. The first female was placed in the male's petri on the day of injection with cotton wool as an oviposition substrate. The female and all eggs were removed at the end of the week (7 days post-injection) and discarded and replaced with a second 7- to 10-day-old virgin female and fresh cotton wool. Again, at the end of the week (14 days post-injection), the female and all resulting eggs were discarded. A third, focal, 7- to 10day-old virgin female was placed with the male with fresh cotton wool. The $3^{\text {rd }}$ female and experimental male were given one week to mate before the male was removed from the petri dish for analysis of testis size and structure. The female was maintained for her lifetime, provided with ad libitum food and water. The eggs produced by the $3^{\text {rd }}$ female were collected

408 from the petri dish twice a week at 3-4 day intervals and the oviposition substrate replaced with 409 fresh cotton wool. The eggs collected were placed in a separate container and allowed to develop 410 to hatching (approximately 7-10 days following collection) and then frozen at $-20^{\circ} \mathrm{C}$ until 411 assayed. We recorded the first collection date for which no eggs hatched. We analyzed the time 412 to end of fertilized eggs due to sperm depletion relative to treatment using a survival analysis 413 (Wilcoxon Rank Sum test) using JMP Pro v14.1. Not all males survived to date of dissection, or 414 their mates died during the course of egg collection, requiring these males to be removed from 415 the analysis, resulting in a sample size of 21 control and $20 \mathrm{ds}-$ Dnmt 1 treated males in the final 416 fecundity analysis.

417 Testis size: At the end of the one-week mating trial with the $3^{\text {rd }}$ female (21 days post-injection), 418 males were dissected and their testes removed into $1 \mathrm{~mL}$ Phosphate Buffered Saline (PBS). 
419 Whole testes were photographed and measured as described above. Not all males survived to

420 date of dissection, resulting in a final sample size of 28 control and $25 \mathrm{ds}-$ Dnmt 1 treated males.

421 Testis tubule structure: Testis tubules from mated males were isolated, fixed and stained as

422 described above.

\section{Acknowledgments}

424 The authors acknowledge Allen J. Moore and other members of the Moore lab for many helpful

425 discussions. We acknowledge Luvika Gupta, who's undergraduate research provided preliminary

426 data used in our experimental design. We also would like to acknowledge Tyler Earp for

427 preparing and analyzing low throughput whole genome bisulfite sequencing data.

428 Competing Interests

429 The authors have no competing interests in regards to this work. 


\section{References}

Amukamara A.U., J. T. Washington, Z. Sanchez, E.C. McKinney, A. J. Moore, R. J. Schmitz, P. J. Moore. More than DNA methylation: does pleiotropy drive the complex pattern of evolution of Dnmt1? Frontiers in Ecology and Evolution 8, 4 (2020).

Bewick, A.J., K. J. Vogel, A. J. Moore, R. J. Schmitz. Evolution of DNA methylation across insects. Molecular Biology and Evolution 34, 654-66 (2016).

Bewick, A.J., Z. Sanchez, E. C. Mckinney, A. J. Moore, P. J. Moore, R. J. Schmitz. Dnmt1 is essential for egg production and embryo viability in the large milkweed bug, Oncopeltus fasciatus. Epigenetics \& Chromatin 12, 6 (2019).

Chesebro, J., S. Hrycaj, N. Mahfooz, A. Popadić. Diverging functions of Scr between embryonic and post-embryonic development in a hemimetabolous insect, Oncopeltus fasciatus. Developmental Biology 329, 142-151 (2009).

Comings, D.E., T. A. Okada. Holocentric chromosomes in Oncopeltus: kinetochore plates are present in mitosis but absent in meiosis. Chromosoma 37, 177-192 (1972). https://doi.org/10.1007/BF00284937

Cunningham, C.B., L. Ji, R. A. W. Wiberg, J. Shelton, E. C. McKinney, D. J. Parker, R. B. Meagher, K. M. Benowitz, E. M. Roy-Zokan, M. G. Ritchie, S. J. Brown, R. J. Schmitz, A. J. Moore. The genome and methylome of a beetle with complex social behavior, Nicrophorus vespilloides (Coleoptera: Silphidae). Genome Biology and Evolution 7, 3383-3396 (2015).

Dallai, R. Overview on spermatogenesis and sperm structure of Hexapoda. Arthropod Structure \& Development 43, 257-290 (2014)._https://doi.org/10.1093/gbe/evy066

Eberhart, C.G., J. Z. Maines, S. A. Wasserman. Meiotic cell cycle requirement for a fly homologue of human Deleted in Azoospermia. Nature 381, 783-785 (1996).

Economopoulos, A.P. H. T. Gordon. Growth and differentiation of the testes in the large milkweed bug, Oncopeltus fasciatus (Dallas). Journal of Experimental Zoology 177, 391-405 (1971).

Ewen-Campen, B., T. E. Jones, C. G. Extavour. Evidence against a germ plasm in the milkweed bug Oncopeltus fasciatus, a hemimetabolous insect. Biology Open 2, 556568 (2013).

Gegner, J., T.Gegner, H. Vogel, A. Vilcinskas. Silencing of the DNA methyltransferase 1 associated protein 1 (DMAP1) gene in the invasive ladybird Harmonia axyridis implies a role of the DNA methyltransferase 1-DMAP1 complex in female fecundity. Insect Molecular Biology 29, 148-159 (2020). https://doi.org/10.1111/imb.12616

Glastad, K.M., B. G. Hunt, M. A. Goodisman. Epigenetics in insects: genome regulation and the generation of phenotypic diversity. Annual Review of Entomology 64, 185-203 (2019). doi.org/10.1146/annurev-ento-011118-111914

Hans, F., S. Dimitrov. Histone H3 phosphorylation and cell division. Oncogene 20, 30213027 (2001). 
Kay. S., D. Skowronski, B. G. Hunt. Developmental DNA methyltransferase expression in the fire ant Solenopsis invicta. Insect Science 25, 57-65 (2018).

Lewis S.H., L. Ross, S. A. Bain, E. Pahita, S. A. Smith, R. Cordaux, et al. Widespread conservation and lineage-specific diversification of genome-wide DNA methylation patterns across arthropods. PLoS Genetics 16, e1008864 (2020). https://doi.org/10.1371/journal.pgen.1008864

Livak, K.J., T. D. Schmittgen. Analysis of relative gene expression data using real-time quantitative PCR and the 2- $\Delta \Delta \mathrm{CT}$ method. Methods 25, $402-408$ (2001).

Lyko, F. The DNA methyltransferase family: a versatile toolkit for epigenetic regulation. Nature Reviews Genetics 19, 81-92 (2018).

Medrano, J.V., C. Ramathal, H. N. Nguyen, C. Simon, R. A. Reijo Pera. Divergent RNAbinding proteins, DAZL and VASA, induce meiotic progression in human germ cells derived in vitro. Stem cells 30, 441-451 (2012).

Meinzer, F., S. Dobler, A. Donath, J. N. Lohr. Robust reference gene design and validation for expression studies in the large milkweed bug, Oncopeltus fasciatus, upon cardiac glycoside stress. Gene 710, 66-75 (2019).

Prigent, C. S. Dimitrov. Phosphorylation of serine 10 in histone H3, what for?. Journal of Cell Science 116, 3677-3685 (2003).

Provataris, P., K. Meusemann, O. Niehuis, S. Grath, B. Misof. Signatures of DNA methylation across insects suggest reduced DNA methylation levels in holometabolan. Genome Biology and Evolution 10, 1185-1197 (2018).

Robinson, K.L., D. Tohidi-Esfahani, F. Ponton, S. J. Simpson, G. A. Sword, N. Lo. Alternative migratory locust phenotypes are associated with differences in the expression of genes encoding the methylation machinery. Insect Molecular Biology 25, 105-115 (2016).

Schmidt, E. D., E. Sehn, A. Dorn. Differentiation and ultrastructure of the spermatogonial cyst cells in the milkweed bug, Oncopeltus fasciatus. Invertebrate Reproduction \& Development 42, 163-178 (2002). DOI:10.1080/07924259.2002.9652773

Schmitz, R. J., Z. A. Lewis, M. G. Goll. DNA methylation: shared and divergent features across eukaryotes. Trends in Genetics 35, 818-827 (2019). doi.org/10.1016/j.tig.2019.07.007

Schmitz, R.J., Y. He, O. Valdés-López, S. M. Khan, T. Joshi, M. A. Urich, J. R. Nery, B. Diers, D. Xu, G. Stacey, J. R. Ecker. Epigenome-wide inheritance of cytosine methylation variants in a recombinant inbred population. Genome Research 23, 16631674 (2013).

Schultz, M.D., R. J. Schmitz, J. R. Ecker. 'Leveling' the playing field for analyses of singlebase resolution DNA methylomes. Trends in Genetics 28, 583-585 (2012). DOI:https://doi.org/10.1016/j.tig.2012.10.012

Schulz, N.K., C. I. Wagner, J. Ebeling, G. Raddatz, M. F. Diddens-de Buhr, F. Lyko, J. Kurtz. Dnmt1 has an essential function despite the absence of CpG DNA methylation 
in the red flour beetle Tribolium castaneum. Scientific Reports 8, 1-10 (2018). https://doi.org/10.1038/s41598-018-34701-3

Shah, C., M. J. VanGompel, V. Naeem, Y. Chen, T. Lee, N. Angeloni, Y. Wang, Y. E. Y. $\mathrm{Xu}$. Widespread presence of human BOULE homologs among animals and conservation of their ancient reproductive function. PLoS Genetics 6, e1001022 (2010). doi.org/10.1371/journal.pgen.1001022

Tanaka, S.S., Y. Toyooka, R. Akasu, Y. Katoh-Fukui, Y. Nakahara, R. Suzuki, M. Yokoyama, T. Noce. The mouse homolog of Drosophila Vasa is required for the development of male germ cells. Genes \& Development 14, 841-853 (2000). preparation for base-resolution whole-genome bisulfite sequencing. Nature Protocols 10, 475-483 (2015). doi: 10.1038/nprot.2014.114

Viera, A., J. Page, J. Rufas. Inverted meiosis: the true bugs as a model to study. In: Benavente, R., Volff J.-N. (eds): Meiosis. Genome Dynamics, Basel, Karger, 2009, vol 5, pp 137-156 (2009). https://doi.org/10.1159/000166639

Yajima, M., G. M. Wessel. The multiple hats of Vasa: its functions in the germline and in cell cycle progression. Molecular reproduction and development 78, 861-867 (2011)

Zemach, A., I. E. McDaniel, P. Silva, D. Zilberman. Genome-wide evolutionary analysis of eukaryotic DNA methylation. Science 328, 916-919 (2010).

Zhang, J. Y. Xing, Y. Li, C. Yin, C. Ge, F. Li. DNA methyltransferases have an essential role in female fecundity in brown planthopper, Nilaparvata lugens. Biochemical and Biophysical Research Communications 464, 83-88 (2015). methylation plays a crucial role during early Nasonia development. Insect Molecular Biology 21, 129-138 (2012). 


\section{Figure Legends}

537 Figure 1. Progression of spermatogenesis in O.fasciatus. In O.fasciatus spermatogenesis

538 progresses from the tip of the testis tubule. (A) Dapi-stained testis tubule of stock male. (B)

539 Diagram of the stages of spermatogenesis. At the apical tip (region I) of each of the seven testis

540 tubules there is a "rosette" of niche cells (blue) surrounded by the germline stem cells (B, green;

541 Schmidt et al. 2002). The rosette is not typically visible in confocal images of testis tubules and

542 markers for the rosette have not been identified yet. As spermatogonia (B, light gray) arise from

543 division of the germline stem cells, they are enclosed by cyst cells (B, yellow). In region II,

544 spermatogonia undergo mitotic transit amplification divisions to form spermatocysts containing

54564 spermatogonia (Economopoulos \& Gordon 1971, Ewen-Campen et al. 2013). Spermatocytes

546 (B, dark gray) in region III divide meiotically. Oncopeltus fasciatus undergoes inverted meiosis

547 (Viera et al. 2009). Primary spermatocytes undergo the first meiotic division to produce diploid

548 secondary spermatocytes. The meiotic division of the secondary spermatocytes produce the

549 haploid spermatids ( $\mathrm{B}$, dark blue) in region IV that then differentiate into spermatozoa in the

550 region $\mathrm{V}$ at the terminal end of the testis tubule.

551 Figure 2. Expression pattern of Dnmt1 within the developing testes mirrored that the two

552 gametogenesis genes Boule and Vasa. Dnmt1 expression (A) was highest in the larval stages

553 where spermatogenesis is initiated compared to the testes of newly emerged (day 0) and virgin

554 sexually mature (day 7-10) adults. This is similar to the expression patterns of Boule (B), in

555 which expression was higher in the $4^{\text {th }}$ and $5^{\text {th }}$ larval stages during which the transition to meiosis

556 occurs compared to newly emerged and virgin sexually mature adults. Expression of Vasa (C)

557 demonstrated a similar pattern, with the highest expression in the $4^{\text {th }}$ instar stage and lowest in

558 sexually mature virgin males. Black dots and bars represent mean and SE. Grey dots represent 
data points for each individual tested. Lower case letters designate significant differences $(p<$ 0.05) among pairwise comparisons using post-hoc Tukey-Kramer HSD test.

561 Figure 2-figure supplement 1. Expression of Dnmt1 is highest in reproductive tissue. As has

562 been seen for females (Amukamara et al. 2020), expression of Dnmt1 varied across the type of

563 tissue in males.. As in females, expression was lowest in the gut and head compared to the other

564 somatic tissue tested, muscle. Expression is highest in the gonad (testes). Lower case letters

565 designate significant differences $(p<0.02)$ among pairwise comparisons using post-hoc Tukey-

566 Kramer HSD test.

567 Figure 3. Expression of Dnmt1 was reduced in the testes of adult males treated with ds-Dnmt1 at

568 both stages of development. Relative gene expression is standardized to expression levels in

569 control treatments. Black dots and bars represent mean and SE. Grey dots represent data points

570 for each individual tested.

571 Figure 3-figure supplement 1. Knockdown of Dnmt1 (magenta bars), but not Boule (blue bars),

572 reduced DNA methylation compared to controls (green bars). Each bar represents a single

573 individual. Across all individuals, the percent methyl $\mathrm{CpG}$ is reduced in the DNA isolated from

574 the adult testis of males treated with $d s$-Dnmt1. Earlier injection reduces the percent methylation

575 to a greater extent, consistent with more rounds of cell division within the testes between

576 injection and dissection

577 Figure 4. Downregulation of Dnmt1 during the $3^{\text {rd }}$ instar stage of development significantly

578 reduced the size of the testis in sexually mature males. There was no effect of downregulation of

579 Dnmt 1 on testis size when treatment occurred during the $5^{\text {th }}$ instar stage of development after

580 meiosis has been initiated. Black dots and bars represent mean and SE. Grey dots represent data

581 points for each individual tested. 


\section{Figure 5 .}

583 Timing of treatment during development determined the effect on testis structure of adults that

584 develop from Dnmt1 (Panels B and D) knockdown males. In control testis tubules from males

585 injected with ds-RED (A and C), spermatogonia divided mitotically in region II to form

586 spermatocysts as is observed in untreated males. Mitotic spermatogonia are labeled with anti-

587 phosophohistone 3 antibodies in region II of the testis tubule (C, arrowhead). Meiotic divisions

588 also occured as in untreated males in ds-RED injected males. In our ds-RED control samples, a

589 band of synchronously dividing spermatocysts, identified by positive anti-phosphohistone H3

590 antibody staining, was present at the interface between primary and secondary spermatocytes (A,

591 C). In testes from males with Dnmt1 knockdown in the $3^{\text {rd }}$ instar (B), the anterior tip of the testis

592 tubule showed evidence of mitotic activity (arrowhead). However, there were fewer

593 spermatocytes present and the spermatocysts in this region were disorganized and there was little

594 evidence of the band of positive anti-phosphohistone H3 stained meiotic spermatocytes. The

595 testis tubule structure from males treated with ds-Dnmt 1 following meiosis at the $5^{\text {th }}$ instar stage

596 of development (D) was more similar to the controls than those treated at the $3^{\text {rd }}$ instar stage of

597 development. In ds-Dnmt1 males treated at the $5^{\text {th }}$ instar stage, there were positive anti-

598 phosphohistone H3 stained spermatogonia (arrowhead) and spermatocytes (arrow). There were

599 differences between males treated as $5^{\text {th }}$ instars with ds-RED males and ds-Dnmt1, however,

600 including spermatocysts containing cells with highly condensed nuclei that were not present in

601 the controls and fewer spermatocysts containing spermatids or spermatozoa. All images taken at

$60210 \mathrm{X}$ magnification.

603 Figure 5-figure supplement 1. Boule knockdown with RNAi showed the expected phenotype in

604 males. (A) ds-Boule RNA treatment reduced Boule expression compared to ds-RED injected 
605 males. Black dots and bars represent mean and SE. Grey dots represent data points for each

606 individual tested. (B) While the anterior end of the testis tubule in Boule knockdown males

607 treated at the $3^{\text {rd }}$ instar stage of development look relatively normal, with spermatogonia dividing

608 normally (B, arrowhead), RNAi resulted in a failure to produce spermatozoa and an abnormal

609 phenotype in region IV. While there was some evidence of anti-phosophohistone 3 staining in

610 spermatocytes (B, arrow), it was reduced and did not mark a transition between spermatocytes

611 and spermatids as is seen in control males. (C) A similar phenotype is seen in males treated with

612 ds-Boule RNA at the $5^{\text {th }}$ instar stage of development. 10X magnification.

613 Figure 6. Females mated to control males lay fertilized eggs longer than females mated to

614 Dnmt1 knockdown males. Eggs were collected twice per week and eggs allowed to develop to

615 hatching. Eggs that did not hatch showed no sign of development, indicating that they had not

616 been fertilized. Both treatments demonstrate a decrease in proportion of eggs that hatch over

617 time, but the ds-Dnmt1 treatment group shows a faster decrease.

618 Figure 6-figure supplement 1: Downregulation of Dnmt1 in sexually mature males resulted in a

619 loss of testis area following multiple matings. Control males allowed to mate with multiple

620 females across three weeks had larger testes than males treated with ds-Dnmt1 at sexual

621 maturity. Black dots and bars represent mean and SE. Grey dots represent data points for each

622 individual tested.

623 Figure 7. Testis structure breaks down in Dnmt1 knockdown males treated as adults after having

624 sperm replenishment induced by mating activity. The regions of spermatogenesis were apparent

625 in mated males following 3 weeks of mating activity in control testis tubules (A and B) and the

626 evidence of both mitotic division in spermatogonia (B, arrowhead) and the band of meiotic

627 divisions was clear from anti-phosphohistone H3 staining. In Dnmt1 knockdown males at low 
628 magnification $(\mathrm{C})$, the anterior tip of the testis tubule looked relatively normal. However, the

629 region containing both the primary and secondary spermatocytes was disorganized.

630 Spermatocyst structure was broken down, and the nuclei of the primary and secondary

631 spermatocytes had lost their characteristic structure (Ewen-Campen et al. 2013). Finally, there

632 were fewer mature spermatids in the posterior end of the testis tubule. At higher magnification

633 (D), it was apparent that nuclear structure in the anterior tip was also affected by the knockdown,

634 both in the spermatogonia and spermatocytes. Spermatogonia nuclei in the Dnmt1 knockdown

635 testis tubules (D) were more condensed than in the control testis tubules (B), although they still

636 seemed to be organized into spermatocysts. Spermatocyte nuclei, however, were fewer in

637 number than in controls, did not have their characteristic shape (Ewen-Campen et al. 2013,

638 Economopoulos \& Gordon 1971), and were not organized in spermatocytes. A and C:10X

639 magnification, B and D: 20X magnification. 
bioRxiv preprint doi: https://doi.org/10.1101/2020.07.23.218180; this version posted February 16, 2021. The copyright holder for this preprint (which was not certified by peer review) is the author/funder, who has granted bioRxiv a license to display the preprint in perpetuity. It is made available under aCC-BY 4.0 International license.

\section{Figure 1}
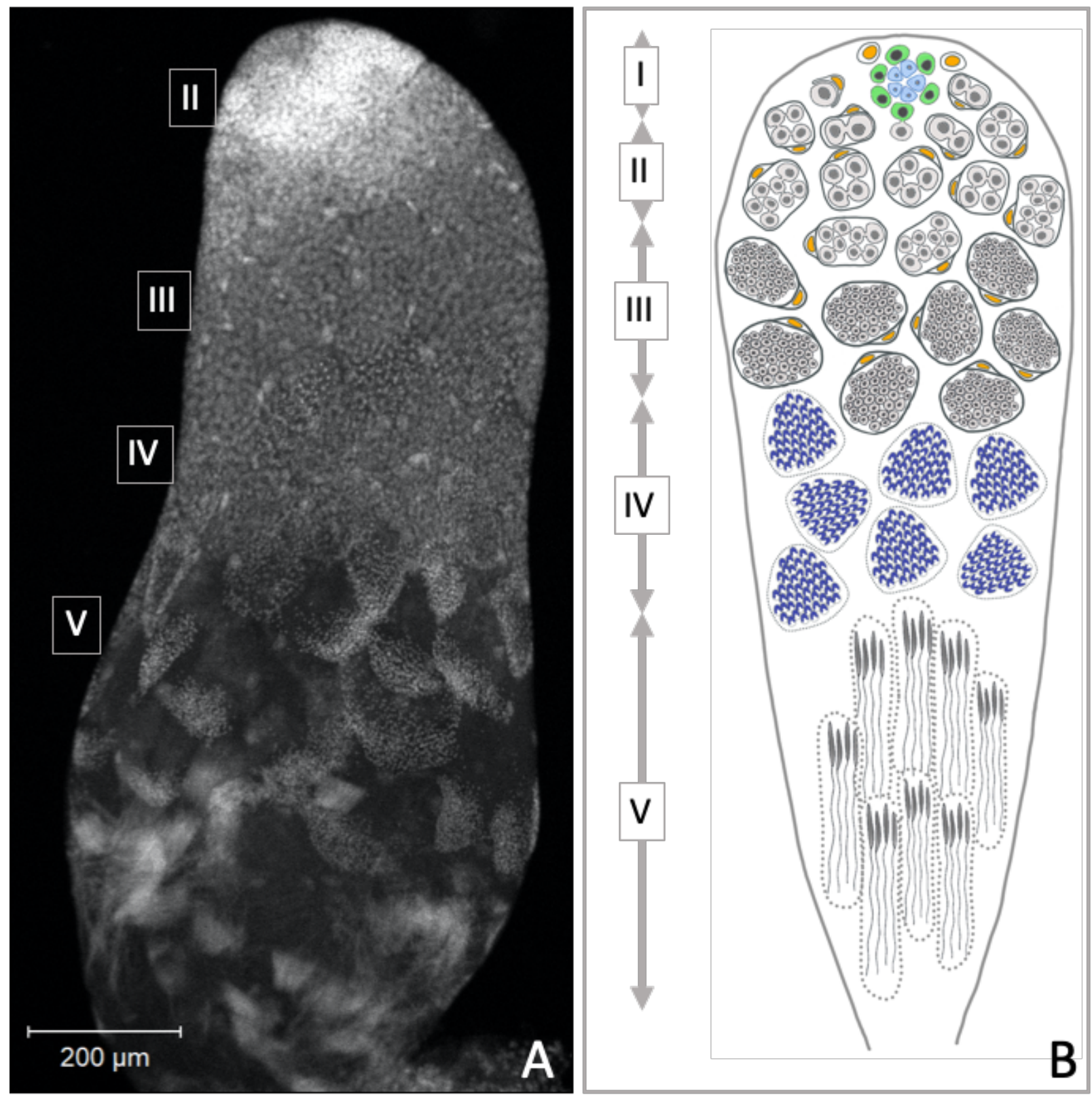
bioRxiv preprint doi: https://doi.org/10.1101/2020.07.23.218180; this version posted February 16, 2021. The copyright holder for this preprint (which was not certified by peer review) is the author/funder, who has granted bioRxiv a license to display the preprint in perpetuity. It is made available under aCC-BY 4.0 International license.

\section{Figure 2.}

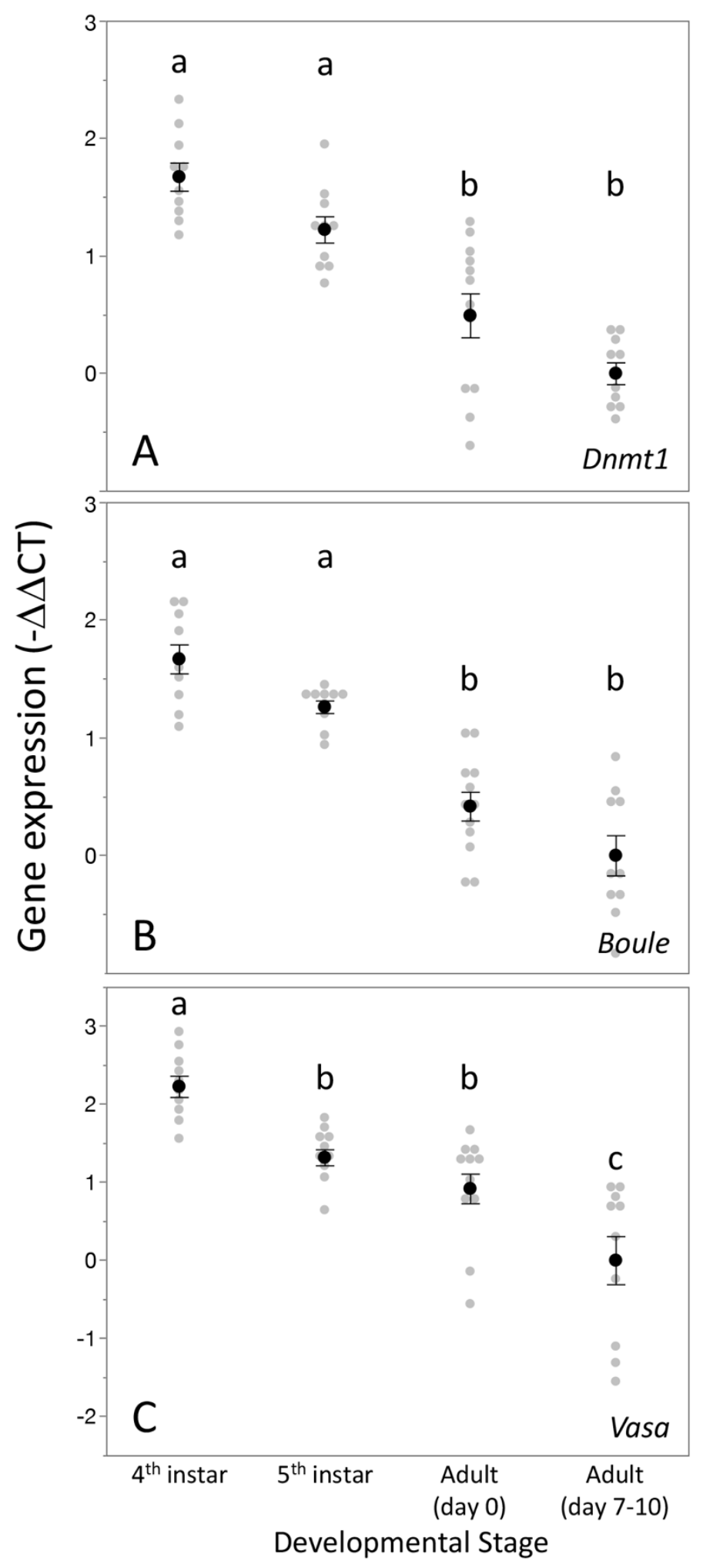

645 
bioRxiv preprint doi: https://doi.org/10.1101/2020.07.23.218180; this version posted February 16, 2021. The copyright holder for this preprint (which was not certified by peer review) is the author/funder, who has granted bioRxiv a license to display the preprint in perpetuity. It is made available under aCC-BY 4.0 International license.

646 Figure 2-figure supplement 1.

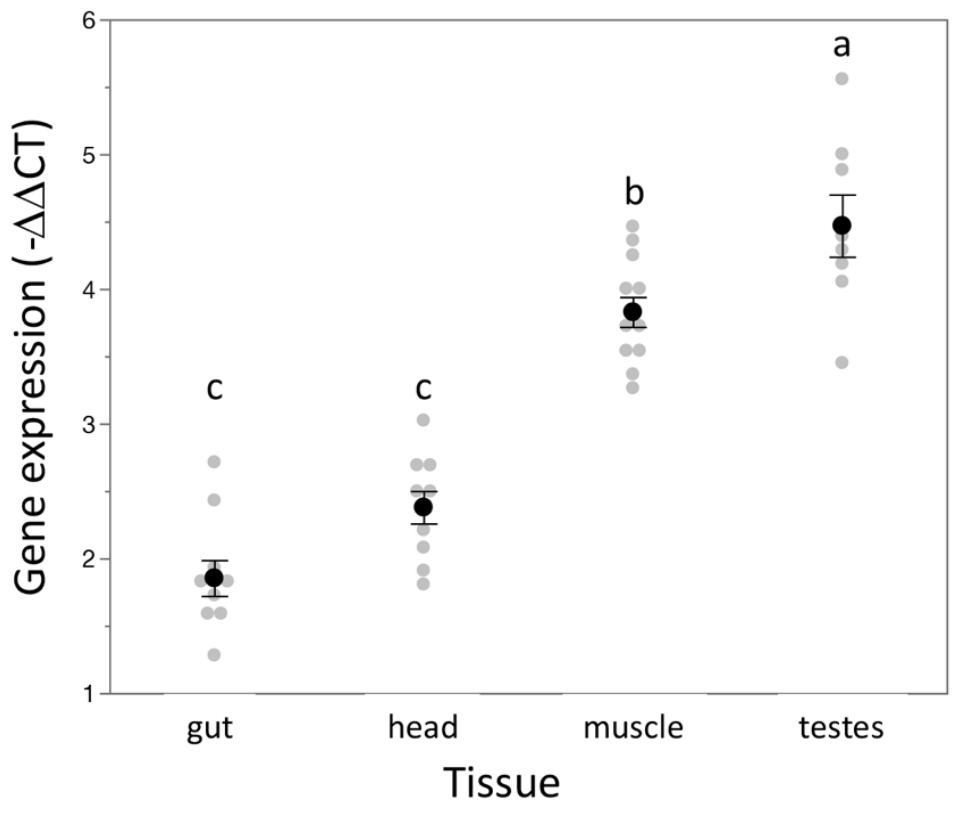


bioRxiv preprint doi: https://doi.org/10.1101/2020.07.23.218180; this version posted February 16. 2021. The copyright holder for this preprint (which was not certified by peer review) is the author/funder, who has granted bioRxiv a license to display the preprint in perpetuity. It is made available under aCC-BY 4.0 International license.

648

Figure 3.
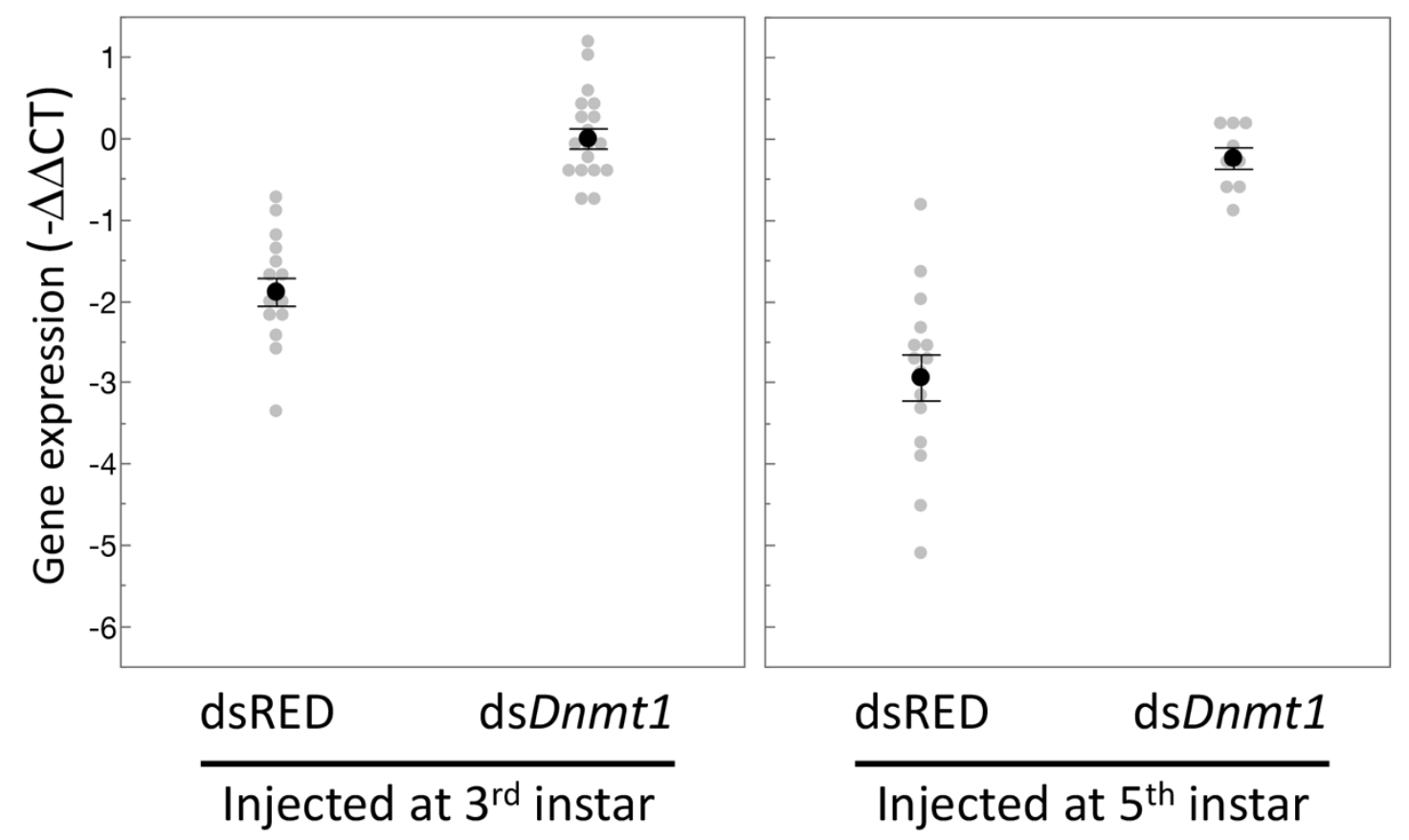

649

650

651 
bioRxiv preprint doi: https://doi.org/10.1101/2020.07.23.218180; this version posted February 16, 2021. The copyright holder for this preprint (which was not certified by peer review) is the author/funder, who has granted bioRxiv a license to display the preprint in perpetuity. It is made available under aCC-BY 4.0 International license.

652 Figure 3-figure supplement 1.

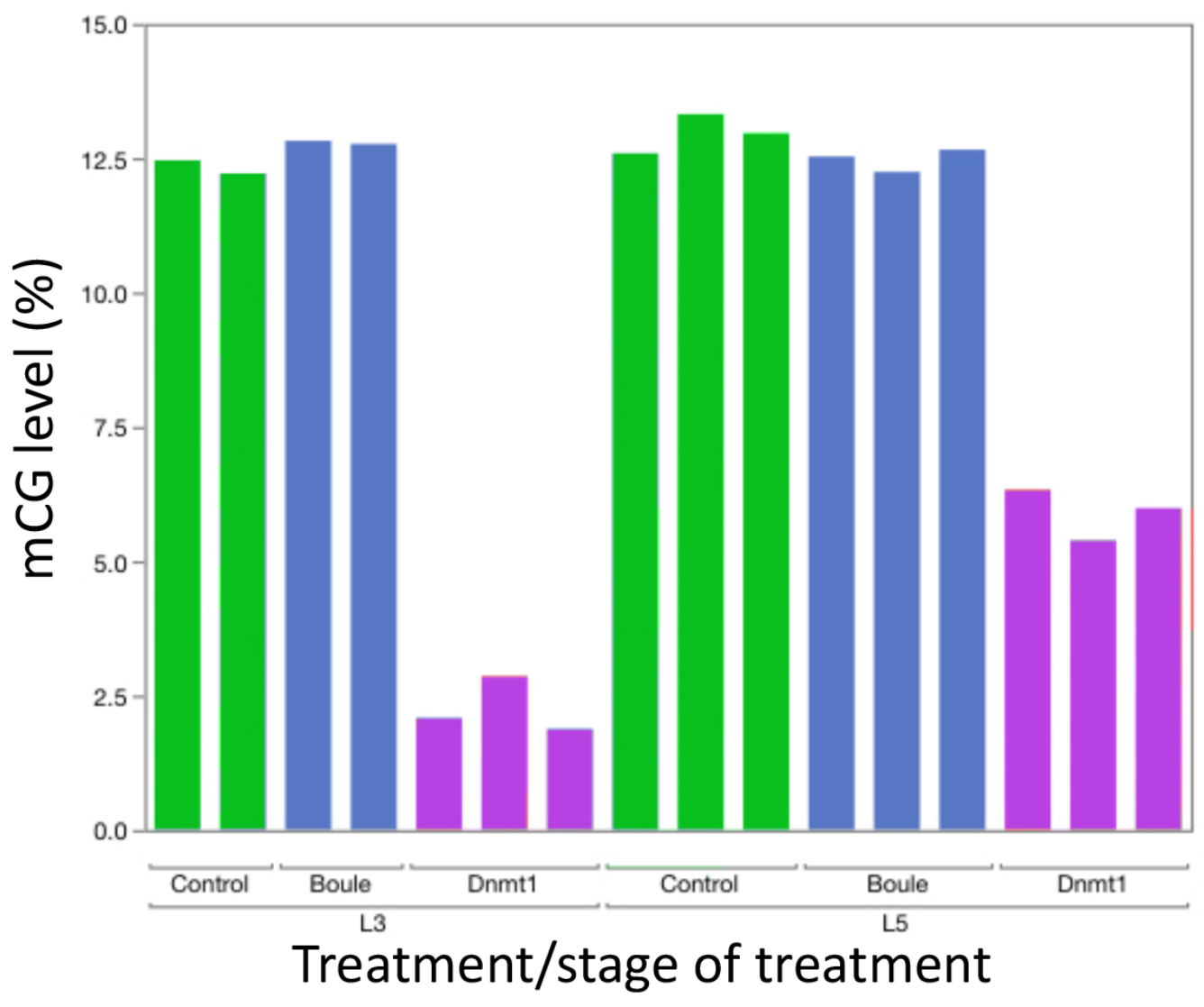

654 
bioRxiv preprint doi: https://doi.org/10.1101/2020.07.23.218180; this version posted February 16. 2021. The copyright holder for this preprint (which was not certified by peer review) is the author/funder, who has granted bioRxiv a license to display the preprint in perpetuity. It is made available under aCC-BY 4.0 International license.

655 Figure 4.

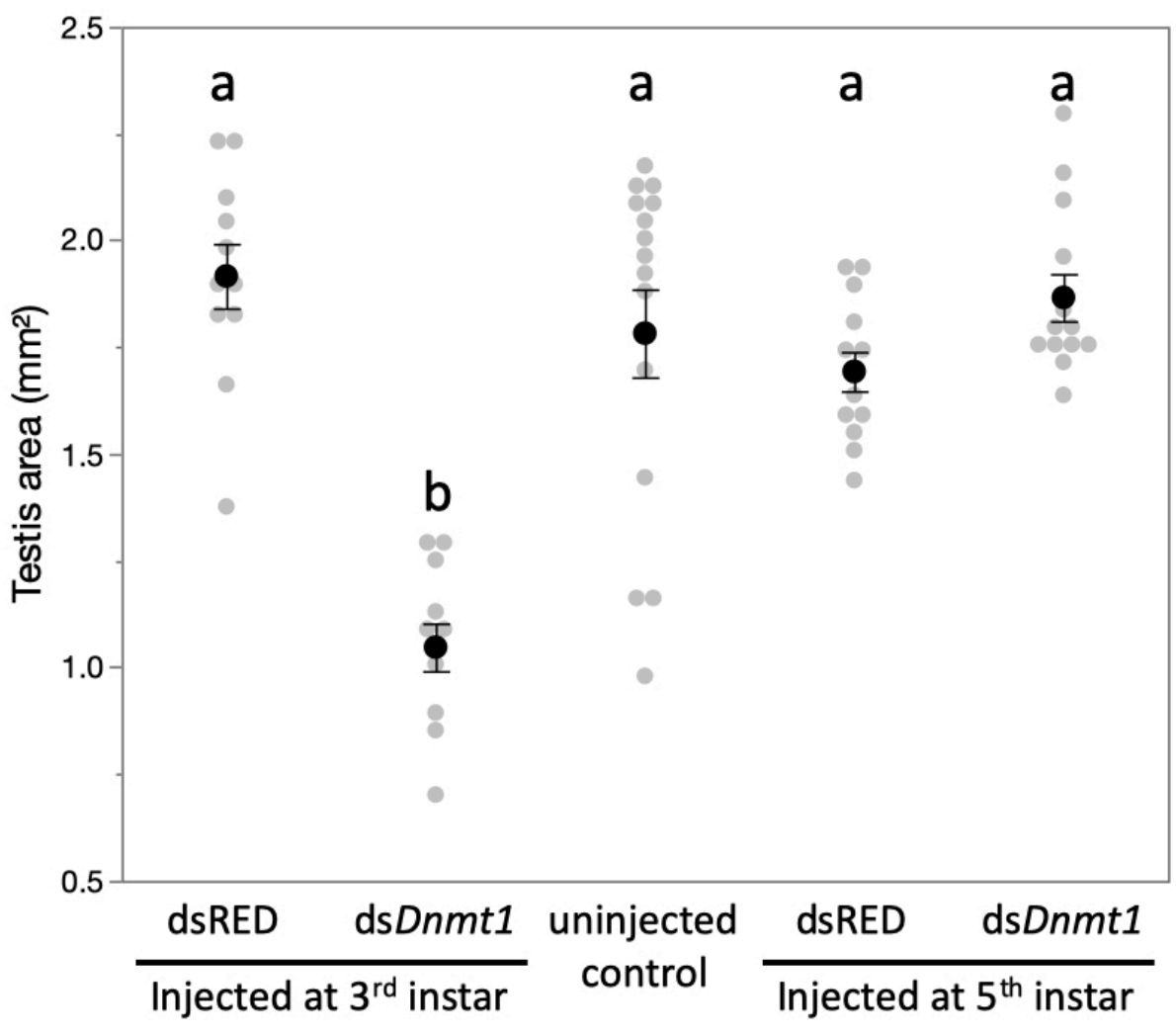

656

657 
bioRxiv preprint doi: https://doi.org/10.1101/2020.07.23.218180; this version posted February 16, 2021. The copyright holder for this preprint (which was not certified by peer review) is the author/funder, who has granted bioRxiv a license to display the preprint in perpetuity. It is made available under aCC-BY 4.0 International license.
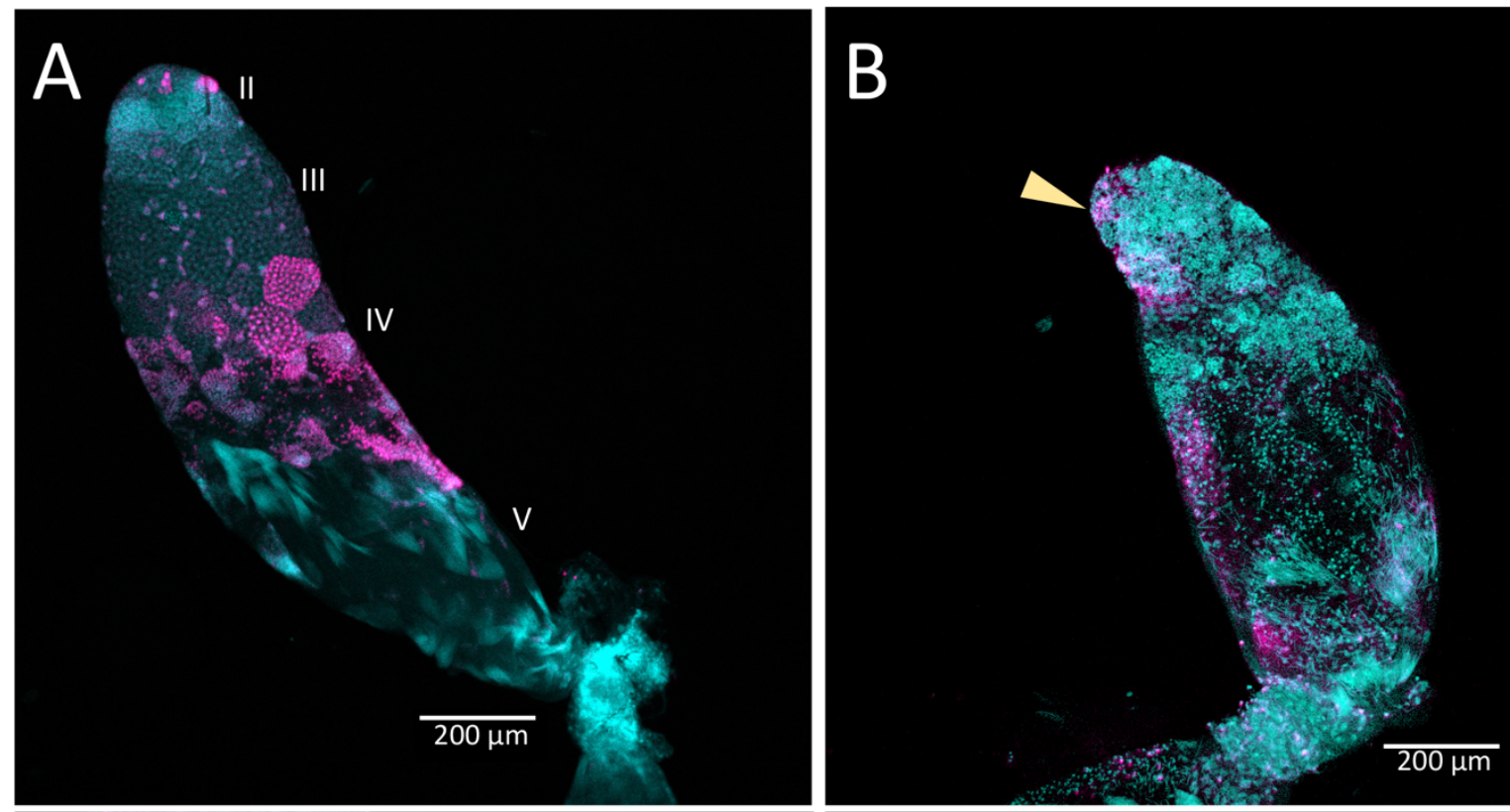

659
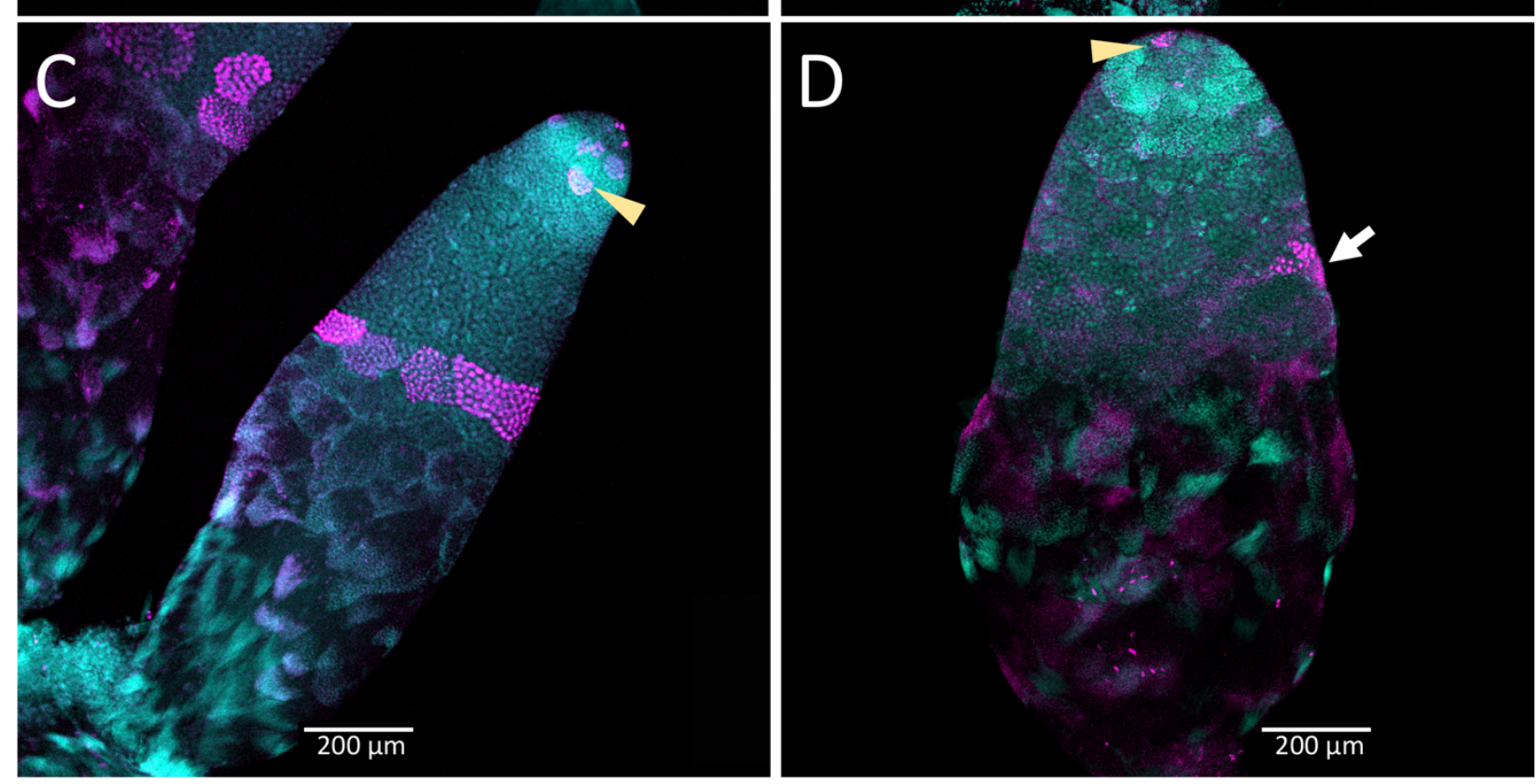

660 
bioRxiv preprint doi: https://doi.org/10.1101/2020.07.23.218180; this version posted February 16, 2021. The copyright holder for this preprint (which was not certified by peer review) is the author/funder, who has granted bioRxiv a license to display the preprint in perpetuity. It is made available under aCC-BY 4.0 International license.

661 Figure 5-figure supplement 1.
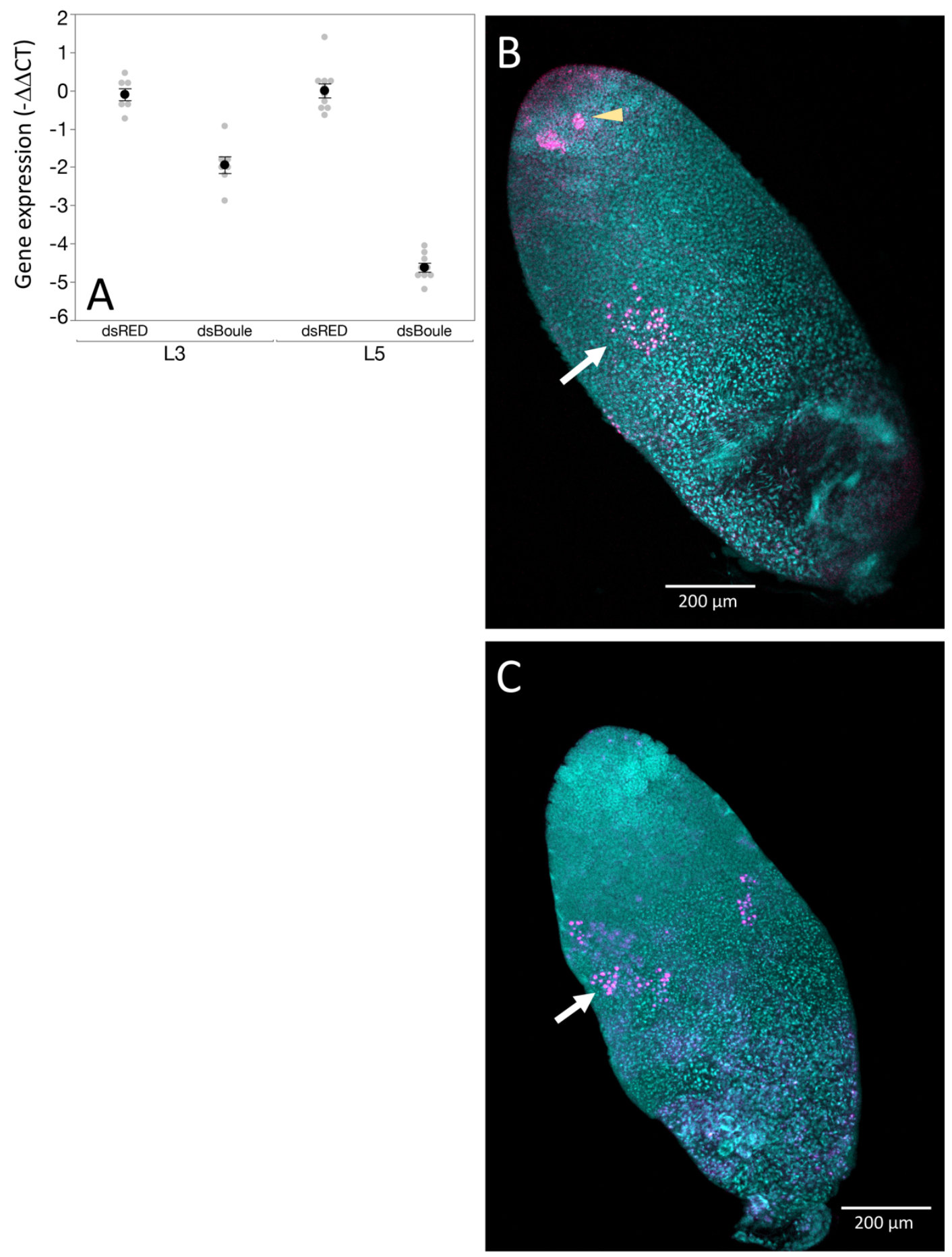
bioRxiv preprint doi: https://doi.org/10.1101/2020.07.23.218180; this version posted February 16, 2021. The copyright holder for this preprint (which was not certified by peer review) is the author/funder, who has granted bioRxiv a license to display the preprint in perpetuity. It is made available under aCC-BY 4.0 International license.

664

665

Figure 6.

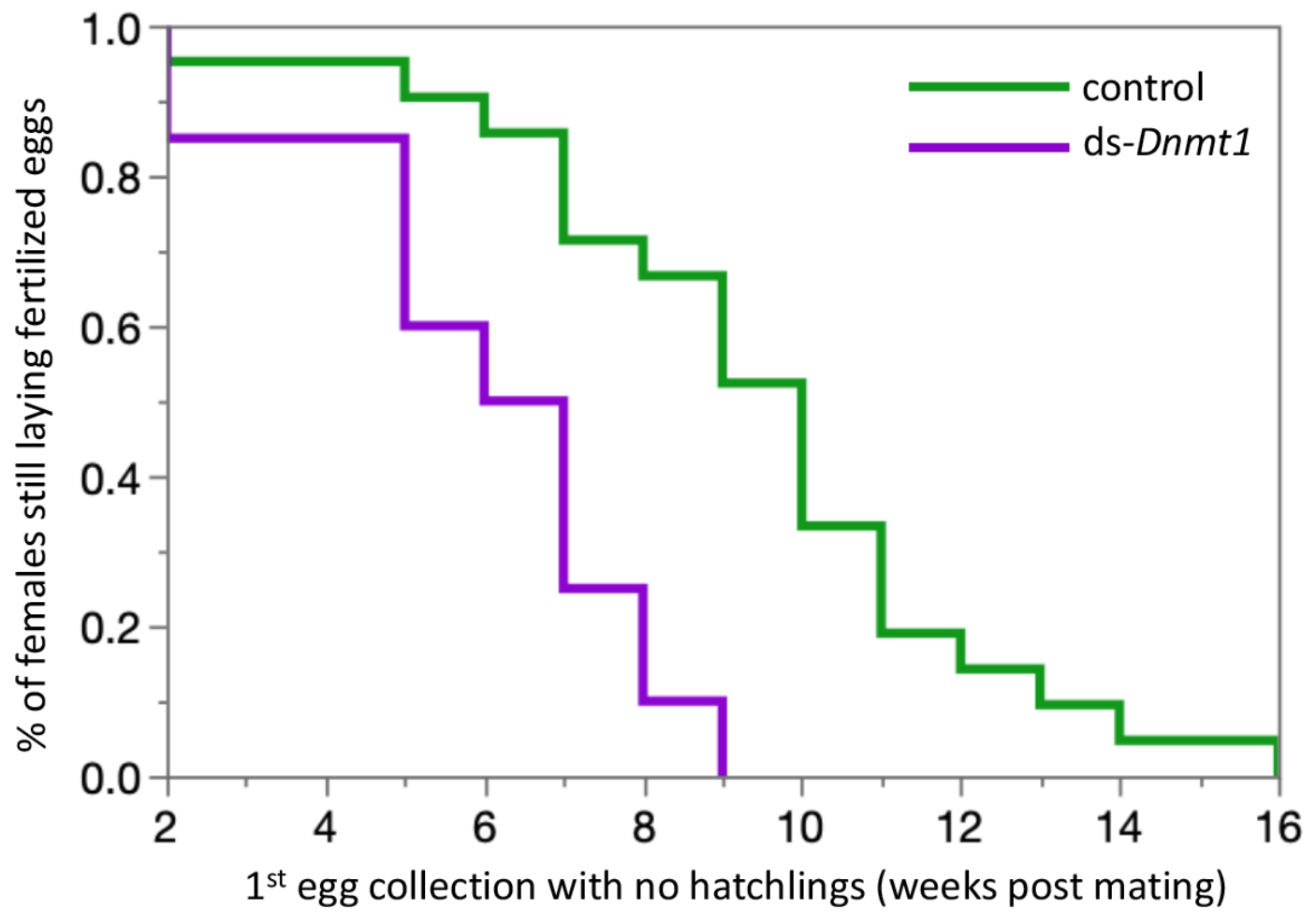

666

667 
bioRxiv preprint doi: https://doi.org/10.1101/2020.07.23.218180; this version posted February 16, 2021. The copyright holder for this preprint (which was not certified by peer review) is the author/funder, who has granted bioRxiv a license to display the preprint in perpetuity. It is made available under aCC-BY 4.0 International license.

668 Figure 6-figure supplement 1.

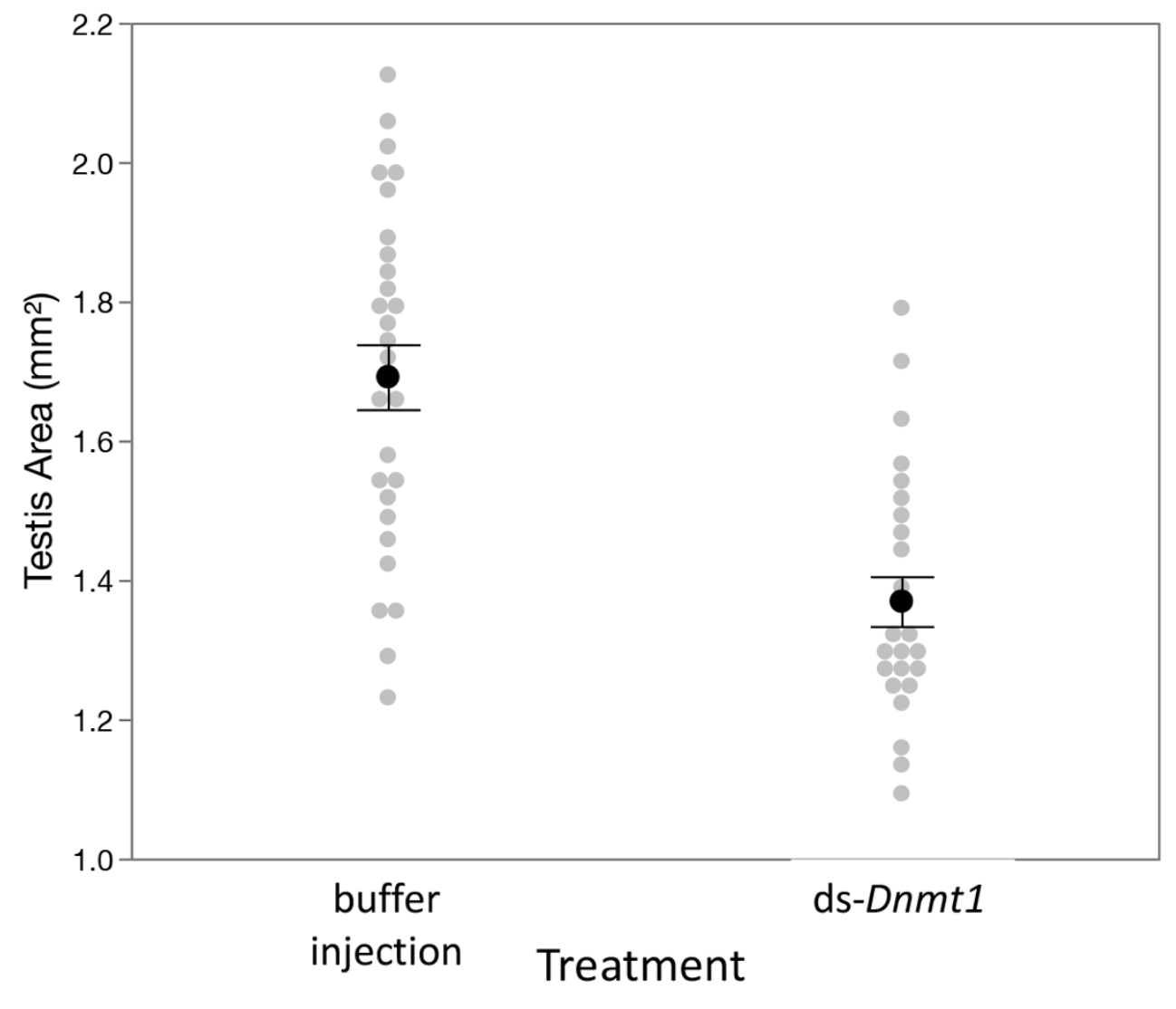

670 
bioRxiv preprint doi: https://doi.org/10.1101/2020.07.23.218180; this version posted February 16, 2021. The copyright holder for this preprint (which was not certified by peer review) is the author/funder, who has granted bioRxiv a license to display the preprint in perpetuity. It is made available under aCC-BY 4.0 International license.

$671 \quad$ Figure 7.
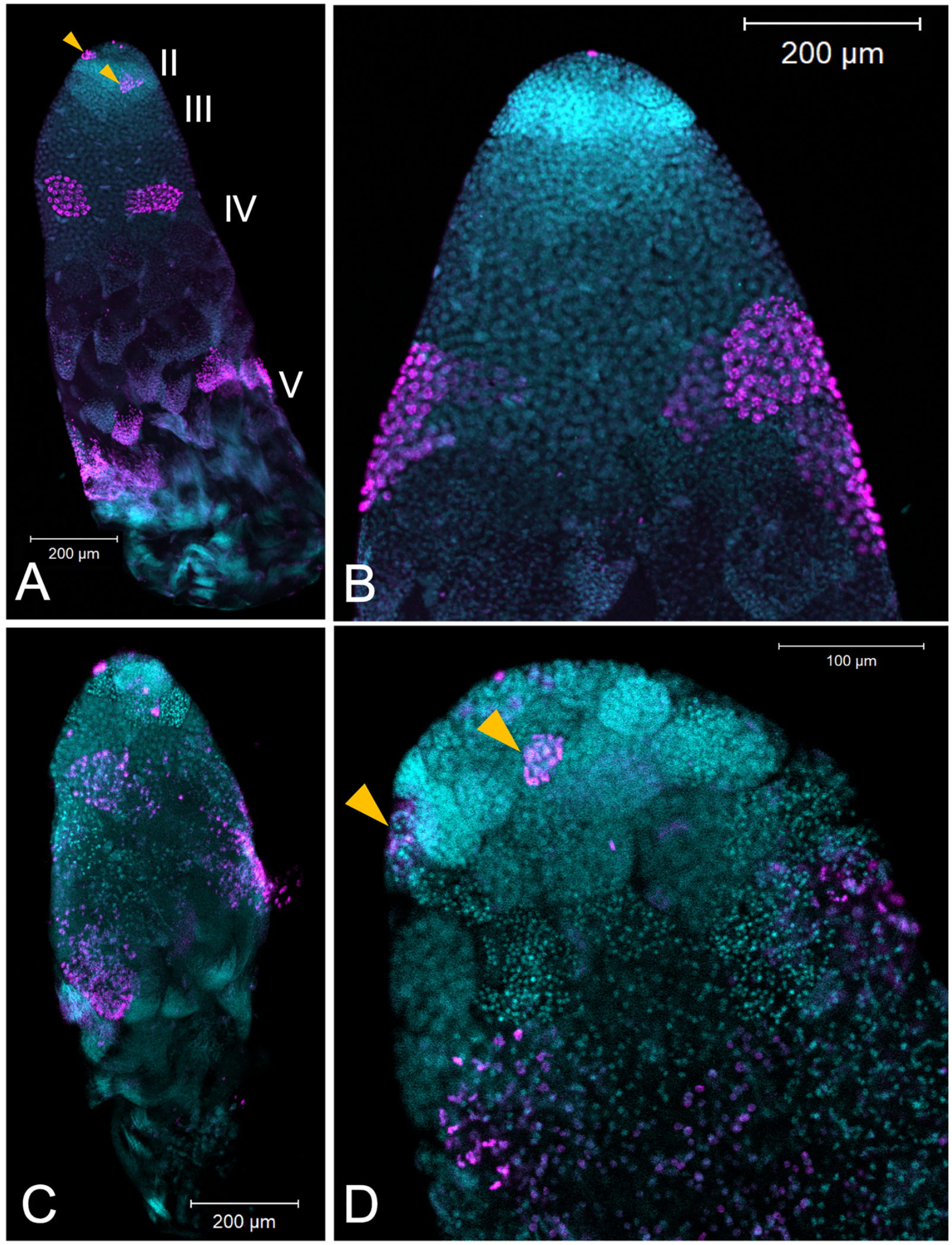